\title{
Lymphoproliferative Disorders of the Lung
}

\author{
Raphaël Borie $^{a}$ Marie Wislez ${ }^{b, d}$ Martine Antoine ${ }^{c, d}$ Jacques Cadranel ${ }^{b, d}$

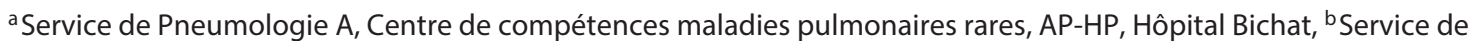 \\ Pneumologie, Centre constitutif maladies pulmonaires rares, and 'Service d'Anatomie pathologique, AP-HP, Hôpital \\ Tenon, and d GRC-THERANOSCAN, Université Pierre-et-Marie-Curie, Université Paris 6, Paris, France
}

\section{Keywords}

Primary pulmonary lymphoma · Mucosa-associated lymphoid tissue · Epstein-Barr virus · Human herpesvirus 8 . Multicentric Castleman disease

\begin{abstract}
This review aims to describe some of the most frequent lymphoproliferative disorders arising from the lung: pulmonary mucosa-associated lymphoid tissue (MALT) lymphoma, lymphomatoid granulomatosis (LG), multicentric Castleman disease (MCD), primary effusion lymphoma (PEL), and nodular lymphoid hyperplasia (NLH). Primary pulmonary lymphoma is defined as a clonal lymphoproliferative disorder affecting one or both lungs, without extrapulmonary involvement 3 months after diagnosis, and includes pulmonary MALT lymphoma and LG. MALT lymphoma is the most common pulmonary lymphoma. The disease is slow growing, most often asymptomatic, and revealed by chronic alveolar opacity on radiography. The diagnosis should involve minimally invasive techniques, and the prognosis is typically excellent. LG is a rare B-cell lymphoma driven by Epstein-Barr virus infection. The disease may mimic pulmonary vasculitis, often revealed by systemic signs. The diagnosis usually requires surgical lung biopsy. Its evolution is unpredictable, but median
\end{abstract}

\section{KARGER}

(C) 2017 S. Karger AG, Basel

E-Mail karger@karger.com

www.karger.com/res survival is poor and chemotherapy is usually proposed. MCD and PEL are both driven by Human herpesvirus 8 infection. Patients with MCD present with fever and lymphadenopathy associated with interstitial lung disease. PEL provokes a febrile, lymphocytic-exudative pleural effusion, without any pleural mass on CT. Specific chemotherapy is urgent for both MCD and PEL. NLH is a benign lymphoproliferative disorder of the lung that is usually asymptomatic and revealed by a single nodular opacity. The prognosis is good, without recurrence after surgical resection.

(c) 2017 S. Karger AG, Basel

\section{Introduction}

Primary pulmonary lymphoma is defined as a clonal lymphoid proliferation affecting the parenchyma and/or bronchi of one or both lungs, with no detectable extrapulmonary involvement at diagnosis or during the following 3 months $[1,2]$. The most common primary pulmonary

Previous articles in this series: 1. Lazor R, Nicod LP: The lung in rare systemic diseases. Respiration 2017;94:1. 2. Tran C, Barbey F, Lazor R, Bonafé L: Pulmonary involvement in adult patients with inborn errors of metabolism. Respiration 2017;94:2-13.

Prof. Jacques Cadranel

Service de Pneumologie, Hôpital Tenon

4 rue de la Chine

FR-75970 Paris (France)

E-Mail jacques.cadranel@aphp.fr 
Table 1. Typical presentation of some lymphoproliferative disorders of the lung

\begin{tabular}{|c|c|c|c|c|c|}
\hline & $\begin{array}{l}\text { Pulmonary MALT } \\
\text { lymphoma }\end{array}$ & $\begin{array}{l}\text { Nodular lymphoid } \\
\text { hyperplasia }\end{array}$ & $\begin{array}{l}\text { Lymphomatoid } \\
\text { granulomatosis }\end{array}$ & $\begin{array}{l}\text { Multicentric Castleman } \\
\text { disease }\end{array}$ & $\begin{array}{l}\text { Primary effusion } \\
\text { lymphoma }\end{array}$ \\
\hline Symptoms & $>50 \%$, asymptomatic & Usually asymptomatic & $\begin{array}{l}\text { Asthenia, fever, or } \\
\text { dyspnea }\end{array}$ & $\begin{array}{l}\text { Dyspnea, fever, } \\
\text { polyadenopathy, and } \\
\text { hepatosplenomegaly }\end{array}$ & $\begin{array}{l}\text { Dyspnea, fever, } \\
\text { altered } \\
\text { performance status }\end{array}$ \\
\hline $\begin{array}{l}\text { CT scan and } \\
\text { PET scan }\end{array}$ & $\begin{array}{l}\text { Unique or multiple } \\
\text { lesions with air } \\
\text { bronchograms with } \\
\text { mild FDG uptake }\end{array}$ & $\begin{array}{l}2 \text { - to } 4 \text {-cm nodule(s) } \\
\text { without FDG uptake }\end{array}$ & $\begin{array}{l}\text { Nodules and mass } \\
\text { with poorly defined } \\
\text { margins with FDG } \\
\text { uptake }\end{array}$ & $\begin{array}{l}\text { Peripheral and mediastinal } \\
\text { lymphadenopathies; small } \\
\text { pleural effusion, reticular } \\
\text { and micronodular opacities; } \\
\text { FDG uptake }\end{array}$ & $\begin{array}{l}\text { Pleural effusion } \\
\text { with FDG uptake }\end{array}$ \\
\hline $\begin{array}{l}\text { Diagnostic } \\
\text { strategy }\end{array}$ & $\begin{array}{l}\text { Transbronchial } \\
\text { biopsy or } \\
\text { percutaneous biopsies }\end{array}$ & $\begin{array}{l}\text { Transbronchial biopsy } \\
\text { or percutaneous } \\
\text { biopsies }\end{array}$ & Surgery & $\begin{array}{l}\text { Lymph node biopsy and } \\
\text { PCR HHV8 in blood }\end{array}$ & $\begin{array}{l}\text { Pleural fluid } \\
\text { examination }\end{array}$ \\
\hline Histology & $\begin{array}{l}\text { Infiltration by clonal } \\
\text { small B cells with } \\
\text { lymphoepithelial } \\
\text { lesions }\end{array}$ & $\begin{array}{l}\text { Follicular hyperplasia, } \\
\text { interfollicular } \\
\text { plasmacytosis }\end{array}$ & $\begin{array}{l}\text { Necrosis and large } \\
\text { aberrant B cells } \\
\text { infected by EBV }\end{array}$ & $\begin{array}{l}\text { Follicular hyperplasia, } \\
\text { involution of germinal } \\
\text { centers, and hyperplasia of } \\
\text { the mantle zone with } \\
\text { "onion-skin" layers; high } \\
\text { HHV8 level in blood }\end{array}$ & $\begin{array}{l}\text { Large aberrant } \\
\text { lymphoid cells } \\
\text { infected by HHV8 } \\
\text { and frequently by } \\
\text { EBV; high HHV8 } \\
\text { level in blood and } \\
\text { pleura }\end{array}$ \\
\hline Treatment & $\begin{array}{l}\text { Localized: Surgery or } \\
\text { radiotherapy } \\
\text { Disseminated: non- } \\
\text { urgent chemotherapy }\end{array}$ & $\begin{array}{l}\text { Surgical excision or } \\
\text { watch and wait }\end{array}$ & $\begin{array}{l}\text { Usually aggressive } \\
\text { chemotherapy }\end{array}$ & $\begin{array}{l}\text { Urgent chemotherapy; } \\
\text { antiviral and antiretroviral } \\
\text { therapy }\end{array}$ & $\begin{array}{l}\text { Urgent } \\
\text { chemotherapy; } \\
\text { antiretroviral } \\
\text { therapy }\end{array}$ \\
\hline
\end{tabular}

MALT, mucosa-associated lymphoid tissue; PET, positron emission tomography; HHV8, Human herpesvirus 8; EBV, Epstein-Barr virus.

lymphoma types in order of decreasing frequency $[1,3]$ are (1) pulmonary mucosa-associated lymphoid tissue (MALT) lymphoma, (2) diffuse large B-cell lymphoma, and (3) lymphomatoid granulomatosis (LG).

We review the kinds of lymphoproliferative disorder that the pneumologist may encounter and that require specific attention, although they may extend beyond this definition. Indeed, nodular lymphoid hyperplasia (NLH) and multicentric Castleman disease (MCD) are not clonal disorders, and primary effusion lymphoma (PEL) does not affect the lung but will be discussed here - but not diffuse large B-cell lymphoma. Each of these lymphoproliferative disorders clinically presents in different ways and is associated with a distinct histological subtype and a specific therapy (Table 1).

\section{Pulmonary MALT Lymphoma}

\section{Mucosa-Associated Lymphoid Tissue}

MALT is a lymphoid tissue that functions to defend the mucosa [1]. Functional B lymphocytes of MALT are memory B cells, involved in immune responses. MALT is physiologically absent from the lung and initially recognized in lungs with infections of an undetermined nature [1]. MALT can also be associated with autoimmune disorders such as Sjögren syndrome.

MALT lymphoma belongs to the group of marginalzone B-cell lymphomas that also include nodal and splenic marginal-zone lymphomas. However, these three subtypes present distinct clinical, morphological, and molecular features [4-8]. In all, $8 \%$ of adults with nonHodgkin lymphoma have MALT lymphoma [9]. MALT lymphoma usually develops from tissues typically devoid of MALT, such as the stomach, salivary glands, lungs, and thyroid. The stomach is the most commonly affected organ, and several features of stomach MALT lymphoma have been extrapolated to other locations such as the lungs.

\section{Etiology}

MALT lymphoma may be considered a model of lymphoma driven by chronic antigen stimulation, whether from autoantigens or a microbial origin [10]. However, an 
infectious agent does not infect or directly transform the lymphoid cells, unlike in lymphomas associated with $\mathrm{Hu}$ man herpesvirus 8 (HHV8) infection (see below) [11]. In MALT lymphoma, the infectious agent increases the risk of lymphoma by chronically stimulating B lymphocytes.

For instance, MALT develops in the stomach with $\mathrm{He}$ licobacter pylori infection that can later transform to lymphoma. H. pylori was formerly detected in $90 \%$ of gastric MALT lymphoma cases, and its eradication was associated with complete remission of the disease in $60-80 \%$ of cases of gastric MALT lymphoma $[12,13]$. The increased use of antibiotics and proton pump inhibitors may have increased the rate of $H$. pylori-negative gastric MALT lymphoma to $50 \%$ [14].

Other infectious agents have been suggested as possible causes of MALT lymphoma at other sites $[10,15,16]$. A causal relationship has been suggested between Campylobacter jejuni infection and small-intestine MALT lymphoma and between Hepatitis $C$ virus infection and some cases of splenic marginal-zone lymphoma. Several studies have also found associations but no proven causal relationship between Borrelia burgdorferi infection and skin MALT lymphoma and between Chlamydophila psittaci infection and ocular adnexal MALT lymphoma.

A causative antigen associated with MALT lymphoma in the lungs has yet to be found. Several studies of pulmonary MALT lymphoma used PCR to detect DNA from Chlamydiaceae, Mycoplasma, or Mycobacterium infection, or a 16S ribosomal RNA-based approach, but the results remained inconclusive [17-19]. In one study, Chlamydiaceae DNA was detected more frequently in MALT than in control tissue, although the difference was not statistically significant. In another study, no mycobacterial DNA was detected. A third study detected DNA from Achromobacter xylosoxidans in 57/124 cases of pulmonary MALT lymphoma versus $15 / 82$ controls $(p=$ 0.004 ) but with no proven causal relationship. Powerful tools developed for analyzing all DNA and RNA present in a given sample [20] could provide evidence for the presence of an unsuspected pathogen in pulmonary MALT lymphoma [21].

Chronic antigen stimulation may also have an autoimmune origin, particularly in the salivary and thyroid glands. A meta-analysis of 29,423 patients showed patients with Sjögren syndrome or systemic lupus erythematosus with an increased risk of marginal-zone lymphoma [22]. Indeed, patients with Sjögren syndrome showed a 6.5-fold increased risk of any type of lymphoma and a 1,000-fold increased risk of salivary gland MALT lymphoma.

Thoracic Lymphomas
Environmental risk factors have not been evidenced in pulmonary MALT lymphoma, although bakers and oil workers have shown increased risks of ocular adnexal and cutaneous MALT lymphoma, respectively [23].

\section{Epidemiology, Clinical Tests, and Imaging}

Pulmonary MALT lymphoma, although rare, represents almost $80 \%$ of primary pulmonary lymphoma cases [24-26]. The disease usually occurs at an age of 50-60 years, very occasionally affecting those under 30 years old [27]. Smoking rates (approx. 35\%) are not higher among people with pulmonary MALT lymphoma than in the general population, and women are affected as often as men [26]. Up to $16 \%$ of patients present features of autoimmune disease [26].

In nearly half of MALT lymphoma cases, patients are asymptomatic at diagnosis, and investigations are initiated after abnormal findings on chest X-ray or CT. When present, symptoms are nonspecific, including cough, dyspnea, and chest pain. Crepitant rales are detected by pulmonary auscultation in less than $20 \%$ of cases. General symptoms such as fever and weight loss are particularly associated with aggressive disease forms [27].

On radiography, MALT lymphoma typically presents as a chronic alveolar localized opacity less than $5 \mathrm{~cm}$ in diameter, and is associated with air bronchograms in nearly $50 \%$ of cases [28-32]. CT (Fig. 1) most frequently shows bilateral and multiple lesions (in $60-77 \%$ of cases) and an intact bronchial lumen in the lesions $[33,34]$. Less than $10 \%$ of cases show diffuse reticulonodular opacities, atelectasis, pleural effusion, or hilar or mediastinal lymphadenopathy [28-30]. The time between the initial abnormal clinical or radiological findings and diagnosis varies from 15 days to 8 years (mean 9 months) [26, 28-31].

Initial staging includes CT scanning of the chest, abdomen, and pelvis, with contrast injection. Bone marrow biopsy is not mandatory but may show MALT lymphoma dissemination in $13-30 \%$ of cases [5, 26, 35-37]. Similarly, concomitant disease in other sites, such as the stomach, is present in $25-35 \%$ of cases and justifies gastroscopy [36-38]. Other mucosal sites that must be assessed in symptomatic patients include the eyes, ears, nose, and throat by MRI or ultrasonography, and the small bowel by camera capsule. The sensitivity and specificity of positron emission tomography (PET) varies depending on the organ involved. The sensitivity in the stomach is $50-$ $89 \%$, versus $80-100 \%$ in the lung, and is very weak in bone marrow [26, 39-42].

The lactate dehydrogenase (LDH) level is usually normal. The $\beta_{2}$-microglobulin level may be an independent

Respiration 2017;94:157-175 DOI: $10.1159 / 000477740$ 


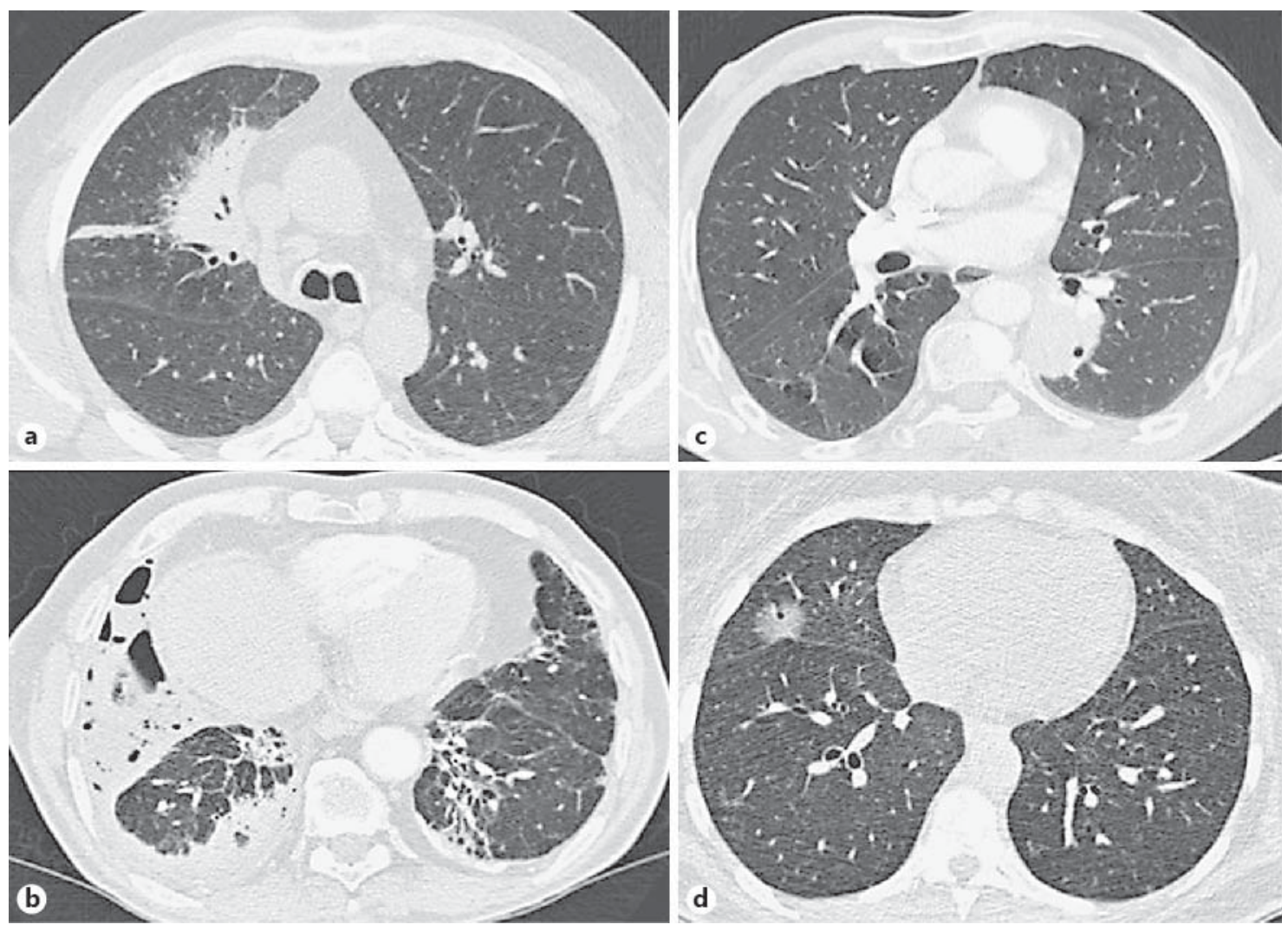

Fig. 1. Representative CT scans of pulmonary mucosa-associated lymphoid tissue (MALT) lymphoma with chronic alveolar opacities, all confirmed histologically to be MALT lymphoma. a Right upper lobe consolidation with air bronchogram. b Left lower lobe consolidation with air bronchogram. c Multifocal consolidations from the right lower lobe and the middle lobe with air bronchogram (the bronchi are distended within the lesions); reticulonodular opacities from the left lower lobe and the left upper lobe. $\mathbf{d}$ Middle lobe ground-glass opacity with a solid component.

prognostic factor [36]. Monoclonal gammopathy is found in $20-60 \%$ of cases, more frequently with plasmacytic differentiation and disseminated disease [26, 28, 30-32].

\section{Diagnostic Strategy}

Tissue biopsy, the gold standard for diagnosis, may be achieved with bronchoscopy or CT-guided needle biopsy. Macroscopic findings of bronchoscopy are usually normal, although abnormalities such as inflammatory mucosa and bronchial stenosis may be observed [28]. Polypoid endobronchial lesions are rare and usually evoke small-cell non-Hodgkin lymphoma. Bronchial and transbronchial biopsies are more fruitful when performed on endobronchial lesions or guided by CT [28]. The sensitivity of bronchial and transbronchial biopsies in detecting MALT lymphoma was reported to be 31 and $88 \%$, respectively [26].
Bronchoalveolar lavage (BAL) performed during bronchoscopy may also aid in the differential diagnosis of chronic alveolar opacities. This technique can indicate the absence of the tumor epithelial cells found in other malignancies such as lepidic adenocarcinoma or the presence of pathogens pointing to a chronic infection. The presence of lymphocytic alveolitis in BAL fluid can also indicate MALT lymphoma [43]. A B-lymphocyte level $>10 \%$ and the demonstration of the clonality of lymphocytes or presence of $\mathrm{t}(11 ; 18)(\mathrm{q} 21 ; \mathrm{q} 21)$ translocation in BAL fluid could be a powerful diagnostic tool, currently underemployed in clinical practice [28, 43-50]. However, a B-cell clone may be absent in BAL fluid in up to $29 \%$ of cases [51].

The sensitivity of CT-guided percutaneous biopsies has been reported to be $80 \%$ [26]. MALT lymphoma has anecdotally been diagnosed on endobronchial ultraso- 


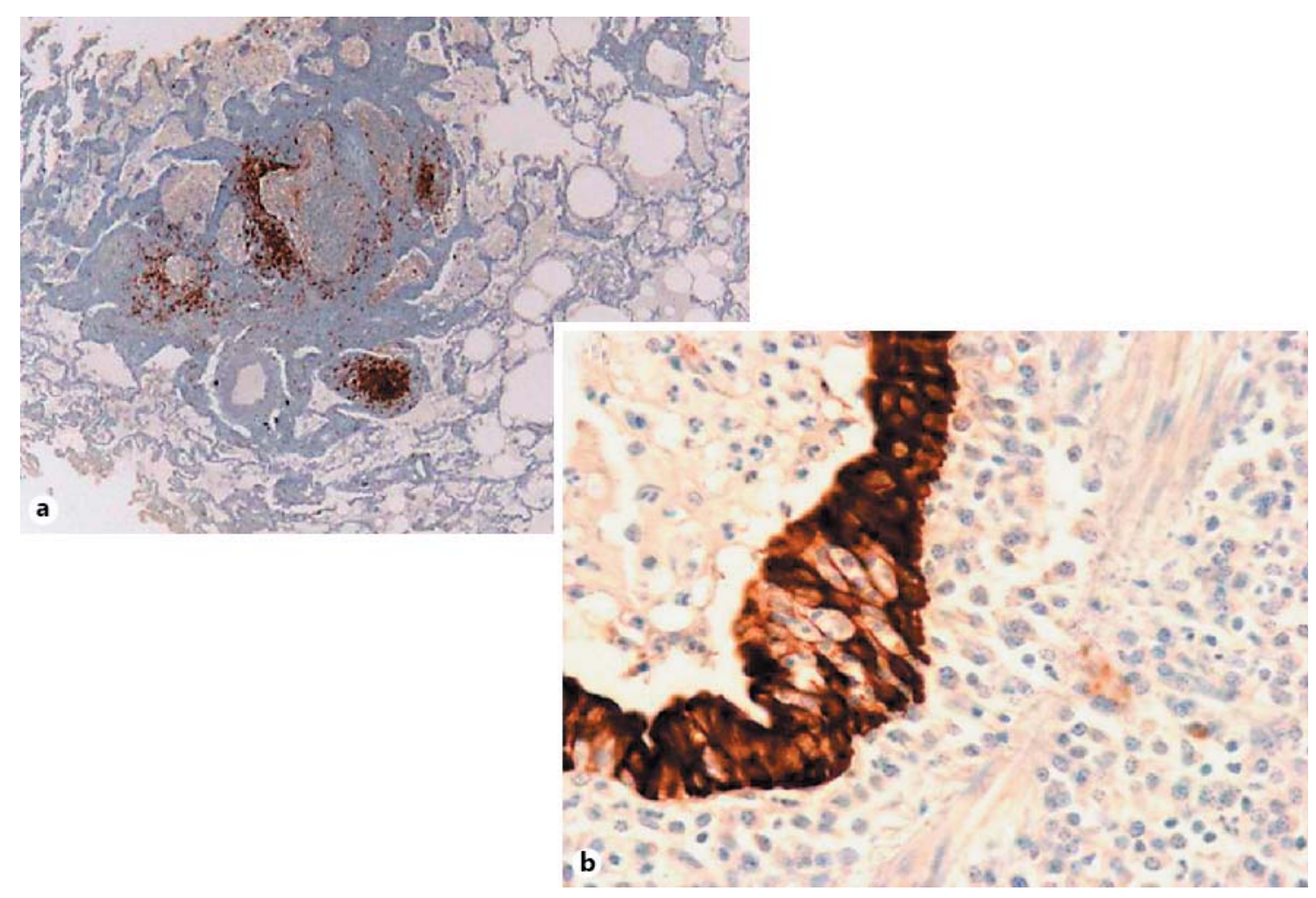

Fig. 2. Representative histology of pulmonary mucosa-associated lymphoid tissue lymphoma with positive CD20 staining (a) and cytokeratin staining in epithelial cells to highlight the lymphoepithelial lesions (b). Courtesy of Dr. Claire Danel, Hôpital Bichat, Paris, France.

nography in experienced hands, with flow cytometry performed on samples [52].

Cryobiopsy could be discussed by experienced teams before diagnostic surgery is performed as a last resort [53]. However, with a localized lesion, surgery provides the opportunity for ultimate treatment performed at the same time as the biopsy.

\section{Diagnosis}

MALT lymphoma is characterized by a lymphoid infiltrate composed of small cells with variable cytologic appearance, including small round lymphocytes, centrocyte-like cells, or monocytoid cells. The tumor cells infiltrate the bronchiolar or alveolar epithelium, thereby causing lymphoepithelial lesions [25, 29, 54-56]. Cohesive sheets of large B cells must suggest the diagnosis of diffuse large B-cell lymphoma.

Plasma cells may be numerous with or without lightchain restriction ( $\kappa$ or $\lambda$ ). The density of infiltration often produces a widening of the alveolar walls and a collapse of the residual alveolar lumen. The airways are often left intact, which agrees with air bronchograms seen on CT. Amyloid deposits, granulomatous reactions, vascular invasion, or fibrosis may be evidenced [56-60].

Immunohistochemistry excludes reactive follicular hyperplasia or secondary localization to the lung with other lymphomas. Tumor cells express B-cell antigens (CD20 and CD79a) but not CD5, a marker of mantle cell lymphoma or chronic lymphocytic leukemia (Fig. 2) [25, 29, 31, 32, 54-57, 61]. Residual lymphoid follicles (CD21/ CD23-positive) and small reactive T lymphocytes (CD3) may be seen $[55,57]$. The proliferative index is usually low (Ki-67 <10\%). Analysis of B-cell clonality is helpful but not sufficient to establish the diagnosis.

The main histological differential diagnoses are NLH and lymphocytic interstitial pneumonia, follicular bronchiolitis, chronic aspecific inflammatory reaction, and other low-grade B-cell lymphomas $[56,62]$. The presence of an intraepithelial CD20/CD43-positive lymphocytic infiltrate is a strong indicator of MALT lymphoma [56]. Molecular analysis is useful to differentiate reactive conditions from lymphoma. 


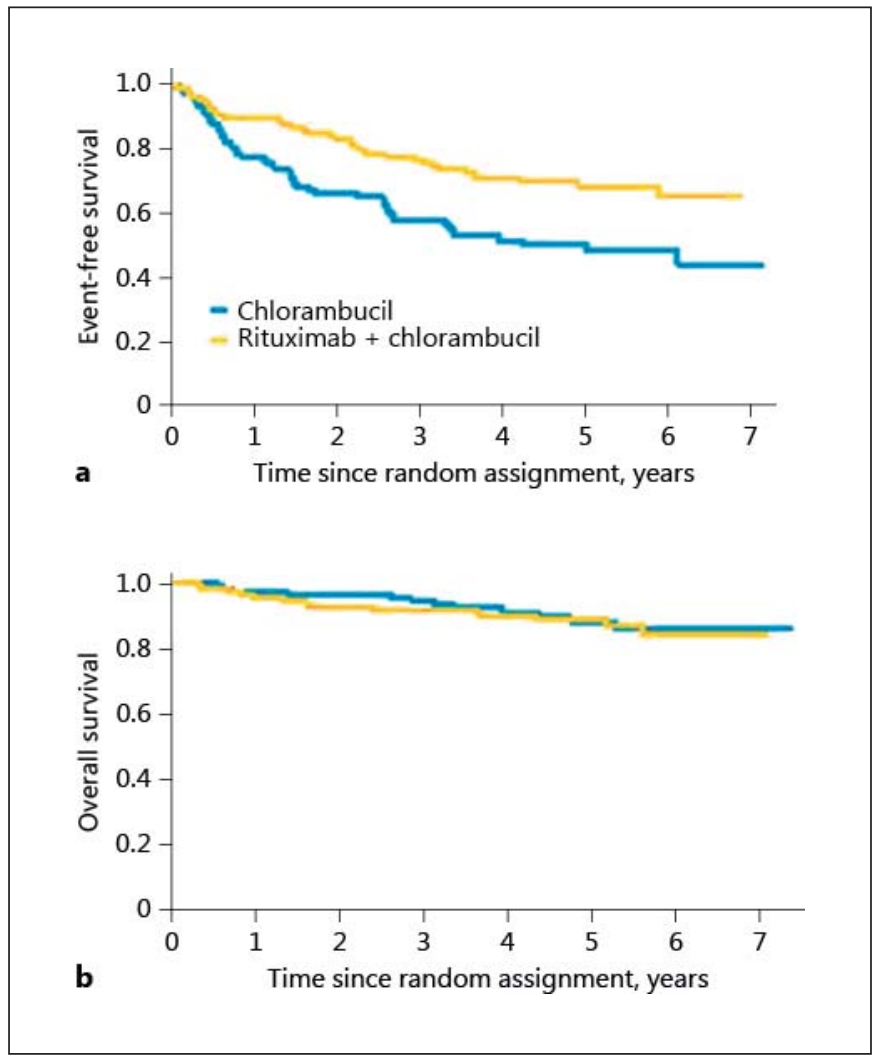

Fig. 3. Event free survival (a) and overall survival (b) in the IELSG randomized study: chlorambucil versus chlorambucil + rituximab in extranodal marginal-zone lymphoma [76]. The 5-year eventfree survival was better with double therapy; however, the 5-year overall survival was not improved.

Lymphoid interstitial pneumonia is a benign lymphoproliferative disorder characterized by diffuse infiltration of the alveolar septa by dense collections of lymphocytes mixed with plasma cells and other cellular elements. The most frequent CT pattern is cysts associated with groundglass infiltrates. Most cases are associated with connective tissue disorders, especially Sjögren syndrome, AIDS, or primary immunodeficiency.

\section{Cytogenetic Abnormalities}

Several cytogenetic abnormalities, although neither related to targeted therapy nor sufficient for diagnosis, have been associated with MALT lymphomas. The frequency and type of cytogenetic abnormalities may vary depending on the lymphoma site.

The most common cytogenetic abnormality is $\mathrm{t}(11 ; 18)$ (q21;q21) translocation [63]. This translocation results in the production of a chimeric protein, API2-MALT1; it is detected in approximately $40 \%$ of pulmonary cases, about $20 \%$ of gastric cases, and circa $15 \%$ of intestinal cases, but is absent in most cases of thyroid, salivary gland, and liver MALT lymphoma $[64,65]$. In gastric MALT lympho$\mathrm{ma}$, the presence of $\mathrm{t}(11 ; 18)(\mathrm{q} 21 ; \mathrm{q} 21)$ translocation is associated with nodal dissemination and resistance to H. pylori antibiotics.

Other, rarer translocations or cytogenetic abnormalities include $\mathrm{t}(1 ; 14)(\mathrm{p} 22 ; \mathrm{q} 32)$ (IGH-BCL10), $\mathrm{t}(14 ; 18)$ (q32;q21) (IGH-MALT1), t $(3 ; 14)(\mathrm{p} 14.1 ; \mathrm{q} 32)$ (FOXP1IGH), and trisomy 3 and $18[63,64]$. Most of these translocations result in the constitutive activation of the NF$\kappa \mathrm{B}$ signaling pathway, which may be specifically targeted. The translocations can be detected by an interphase fluorescence in situ hybridization assay of formalin-fixed paraffin-embedded tissue or RT-PCR of frozen tumor samples [63].

Finally, MALT lymphoma could develop as a result of both cytogenetic abnormalities and antigenic stimulation. Illustrating this point, a mouse genetically modified to overexpress API2-MALT1 showed lymphoma only after antigenic stimulation [66-68].

\section{Treatment and Prognosis}

Recent recommendations for gastric MALT lymphoma have been reported $[69,70]$. Because no microorganism is identified in the lung, therapeutic options are surgery, chemotherapy, immunotherapy, radiotherapy, or "watch and wait" [71]. In localized lesions, surgical resection or radiotherapy may be considered; radiotherapy is associated with lower morbidity than is surgery $[28,30$, 72-74].

In other cases, chemotherapy is preferred. Treatment with single-agent chemotherapy (chloraminophene or fludarabine) is not less preferred than multiple-agent chemotherapy (cyclophosphamide, adriamycin, vincristine, and prednisone; $\mathrm{CHOP}$ ) $[26,28]$. Rituximab alone is effective, with a $70 \%$ response rate, but associated with a $36 \%$ disease recurrence [75].

The first double-blind, phase III study of MALT lymphoma included 231 patients and compared chlorambucil to rituximab-chlorambucil [76]. The 5-year eventfree survival was better with double therapy than with monotherapy (68 vs. $50 \%, p=0.02$ ) (Fig. 3). Double therapy increased the complete response rate (78 vs. $65 \%)$ [76]. However, the 5-year overall survival (89\%) was not improved, and grade 3-4 neutropenia was more common with double therapy than with monotherapy. Rituximab alone was also evaluated and the results are still expected.
Borie/Wislez/Antoine/Cadranel 
In a retrospective cohort of gastric MALT lymphoma cases, rituximab-chloraminophene was more efficient than rituximab alone in $\mathrm{t}(11 ; 18)$-positive patients, and rituximab alone was as efficient as double therapy in $\mathrm{t}(11 ; 18)$-negative patients $[77,78]$.

Numerous currently available therapies have had antitumoral effects, such as purine analogues (fludarabine and cladribine), pentostatin, NF- $\kappa B$ inhibitors (bortezo$\mathrm{mib}$ ), or a combination of mitoxantrone and bendamustine [70, 79-85]. However, the respective value of each treatment is difficult to estimate [86]. Moreover, numerous phase II/III studies of marginal-zone lymphoma are evaluating compounds currently developed for other lymphomas (anti-btk, anti-CD20 antibody, etc.) [87].

The prognosis with MALT lymphomas is good, with 5 -year overall survival $>80 \%$ and a median survival of $>10$ years $[25,26,28-32,36-38,54,59,88]$. A long period of monitoring is required, even after surgical resection, because almost $50 \%$ of patients show recurrence, either at the same location or outside the thoracic region $[28,32$, $54,59,61]$.

None of the following factors are associated with prognosis: gender, delay to diagnosis, symptoms, bilateral or unilateral lesions, or extrapulmonary involvement [26]. With a multivariate analysis including all localizations of MALT lymphoma, predictors of prognosis were an elevated $\beta_{2}$-microglobulin level and stage IV classification according to the Ann Arbor system [36, 89].

Very recently, Thieblemont et al. [90] proposed a simple classification including age $>70$ years, Ann Arbor stage $>2$, and elevated LDH level. In a cohort of 393 patients, the addition of these three factors discriminated three risk groups with different 5 -year progression-free survival rates $(78,63$, and $29 \% ; p<0.001)$ and 5 -year overall survival rates $(99,92$, and $74 \%$; $p<0.001)$.

\section{Nodular Lymphoid Hyperplasia}

\section{Definition}

NLH is a rare disease characterized by a nonclonal lymphoproliferation that usually forms a single nodule or, more rarely, multiple pulmonary nodules.

\section{Clinical Presentation and Complementary}

\section{Examinations}

NLH may occur as a solitary lesion in patients without autoimmune disease or immunodeficiency. It may also be associated with combined variable immunodeficiency or, less frequently, with Sjögren syndrome and form a disease

Thoracic Lymphomas called granulomatous-lymphocytic interstitial lung disease that is frequently associated with extrapulmonary localizations [91]. For clarity, only idiopathic NLH is discussed here.

There is no gender predominance, and the mean age at diagnosis is 60 years (range 18-80) [62, 92]. Some patients may present with cough or dyspnea, particularly with tracheal involvement, although the most frequent localization is parenchymal. Indeed, most patients are asymptomatic.

CT reveals a unique 2 - to $4-\mathrm{cm}$ nodule in $64 \%$ of cases (Fig. 4). One-third of the patients present with multiple nodules, and one-third with lymphadenopathy, hilar or mediastinal [62]. NLH usually does not show FDG uptake on PET scans, although a mild increase in uptake may be seen, particularly with cavitary lesions [93]. Blood tests are not helpful.

\section{Diagnosis}

The diagnosis of NLH is established by histology and requires exclusion of the differential diagnoses, particularly MALT lymphoma [94]. Although the diagnosis may be attempted with transbronchial or transthoracic biopsy, NLH features may also be involved in lung cancer or lymphoma, which cannot be excluded without surgical excision.

The typical histology is follicular hyperplasia, interfollicular plasmacytosis, and a variable degree of fibrosis. Immunohistochemical analysis (of CD3, CD20, etc.) is consistent with a reactive process, without an aberrant lymphocyte phenotype (Fig. 4) [62].

Unlike MALT lymphoma, none of the following features is present: lymphoepithelial lesions, amyloid deposits, B-cell clonality, light-chain restriction, or presence of $\mathrm{t}(11 ; 14)$ translocation. NLH and hyper-IgG4 syndrome may coexist. However, in a recent series of 26 cases of NLH retrospectively assessed, none fulfilled the diagnosis of hyper-IgG4 syndrome. Moreover, none showed positive Epstein-Barr virus (EBV)-encoded RNA (EBER) staining [95].

\section{Prognosis and Treatment}

The only treatment reported is surgical excision, with excellent prognosis without recurrence. However, Kajiwara et al. [96] reported a case of natural regression. A watch-and-wait policy may be also discussed with this nonclonal disease. Because the disease is not fully understood from an etiological or evolutionary viewpoint, and with the risk of transformation to lymphoma, long-term follow-up is required.

Respiration 2017;94:157-175 163 

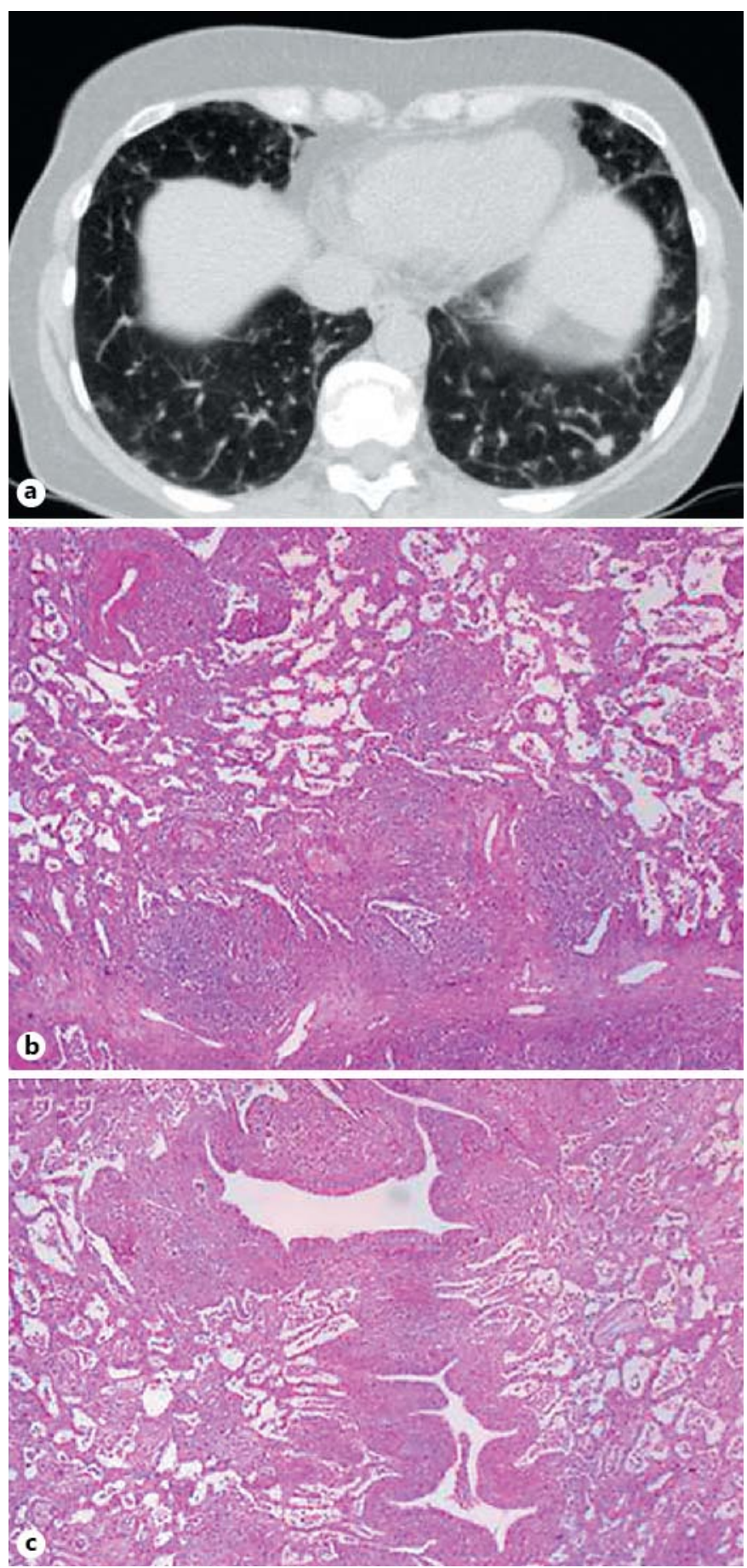

Fig. 4. a CT scan of nodular lymphoid hyperplasia from the left lower lobe in the context of granulomatous-lymphocytic interstitial lung disease associated with combined variable immunodeficiency. b, c Lymphoid hyperplasia with lymphoid nodules along bronchioles in common variable immunodeficiency.
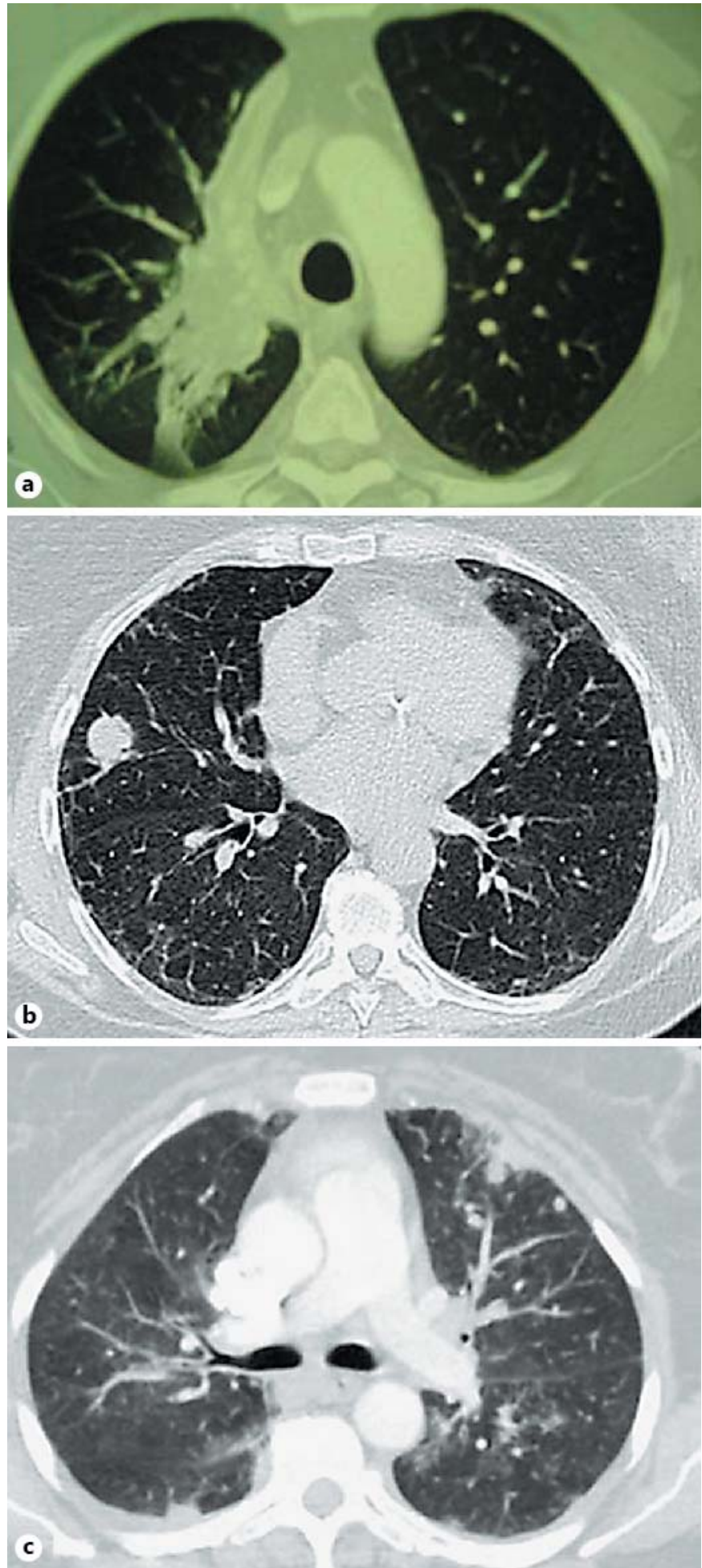

Fig. 5. Representative CT scans of lymphomatoid granulomatosis with nodules or a mass. a Spiculated $6-\mathrm{cm}$ mass from the right upper lobe. $\mathbf{b} 1.5-\mathrm{cm}$ nodule from the middle lobe associated with interstitial lung disease with diffuse ground-glass opacities. c Multiple nodules of different size with lower lobe predominance. All patients required surgical biopsy for the diagnosis. 


\section{Lymphomatoid Granulomatosis}

\section{Definition}

LG is a rare B lymphoma associated with EBV infection [97]. It is frequent with immunodepression: autoimmune disease, AIDS, or solid-organ transplantation [98]. The prevalence is unknown, and about 600 cases have been reported [99-102].

\section{Clinical Presentation and Complementary}

\section{Examinations}

The median age at diagnosis is $30-50$ years, with a male/female ratio of $2 / 1$ [100]. About $90 \%$ of patients are symptomatic, and the symptoms are frequently present for several months: general signs $(50 \%)$ or respiratory signs (75\%) [99].

The lung is involved in $80 \%$ of cases [99]. Nodules and a mass with poorly defined margins are frequent patterns seen on CT. Nodules are more frequent along the bronchovascular structures or interlobular septa and in the base (Fig. 5). The nodules may grow, form cavities, or spontaneously disappear [97]. Skin manifestations occur in $30-50 \%$ of cases: erythematous plaques, and nodules with predominance on the trunk and extremities [99].

Neurological manifestations occur in approximately $30 \%$ of cases. Symptoms may vary depending on the localization of the disease: the central or peripheral nervous system (confusion, paraplegia, hemiparesis, and ataxia), cranial nerves (hearing loss, diplopia, and dysarthria), or neurovegetative system (atonic bladder) [103]. MRI reveals multiple focal intraparenchymal lesions with increased signals on FLAIR and T2-weighted MRI images. This pattern may also be seen with neurological involvement of sarcoidosis, lymphoma, or vasculitis. Cerebrospinal fluid analysis may show an increased number of lymphocytes or a heightened protein level [103].

Ear, nose, and throat manifestations occur in $10-30 \%$ of cases and may mimic granulomatosis with polyangiitis (formerly Wegener granulomatosis) [104]. Renal involvement occurs in $10-40 \%$ of cases, mostly presenting as a mass seen on CT without renal insufficiency or proteinuria [105]. Other manifestations such as enlarged lymph nodes are rare.

Clinical staging requires specialized neurological and cutaneous evaluation, and radiological staging requires brain MRI and PET. PET may reveal renal, skin, nodal, and pulmonary involvement and may be used to evaluate response to therapy [106].

The complete blood count is normal in more than $50 \%$ of cases, although lymphopenia or hyperleukocytosis may be seen $[97,100]$. Half of the cases present polyclonal hypergammaglobulinemia. EBV serology is positive, and the EBV viral load is increased without specificity, with a mean of 18 copies $/ 10^{6}$ genome equivalents [97].

\section{Diagnosis}

A diagnosis of LG requires histology, most frequently obtained by surgical lung biopsy for lung involvement, because tissues obtained by bronchoscopy rarely allow for a diagnosis. However, a diagnosis may be obtained by skin biopsy or by ear, nose, and throat biopsy [97]. Sampling from all accessible sites is recommended, because tumoral infiltration and EBV staining vary between sites [97].

The distribution of the lesions is patchy and the surrounding lung is almost normal, although fibroblastic foci may be seen at the periphery, as well as organizing pneumonia or edema. The lesions are angiocentric and associated with various degrees of necrosis [97, 107]. Contrary to the name of the disease, there is no granuloma, but a polymorphous infiltrate compound of lymphocytes and histiocytes is seen - and, rarely, plasma cells [100].

Most of the small lymphocytes are T cells (CD3/CD4). Atypical large cells and "ghost cells" are lymphoid (CD45) and are highlighted by CD20 immunostaining within the necrotic area. They may present an aberrant phenotype (CD20/CD43) [108]. They are stained on in situ hybridization for EBER, whereas staining for the latent membrane protein of EBV is positive in only $70 \%$ of cases (Fig. 6). The B cells are monoclonal, but clonality analysis is not required for the diagnosis, whereas EBER staining is almost mandatory, even if findings may be negative for up to $50 \%$ of cutaneous lesions $[97,99]$.

Finally, LG is histologically classified from grade 1 to grade 3 depending on the number of tumoral cells: grade 1, no large atypical cells, little necrosis, rare EBV-positive cells; grade 2, occasional large atypical cells, moderate necrosis, 5-20 EBV-positive cells/field; and grade 3, predominant population of large atypical cells that may be confluent and associated with extensive necrosis [109]. Indeed, atypical large lymphoid cells may be difficult to detect in low-grade lesions without specific immunostaining.

An infectious disease must be excluded particularly in localized diseases. Differentiating LG from granulomatosis with polyangiitis and necrotizing sarcoidosis may be difficult. Hodgkin lymphoma and other aggressive lymphomas also must be excluded.

Respiration 2017;94:157-175

Thoracic Lymphomas 

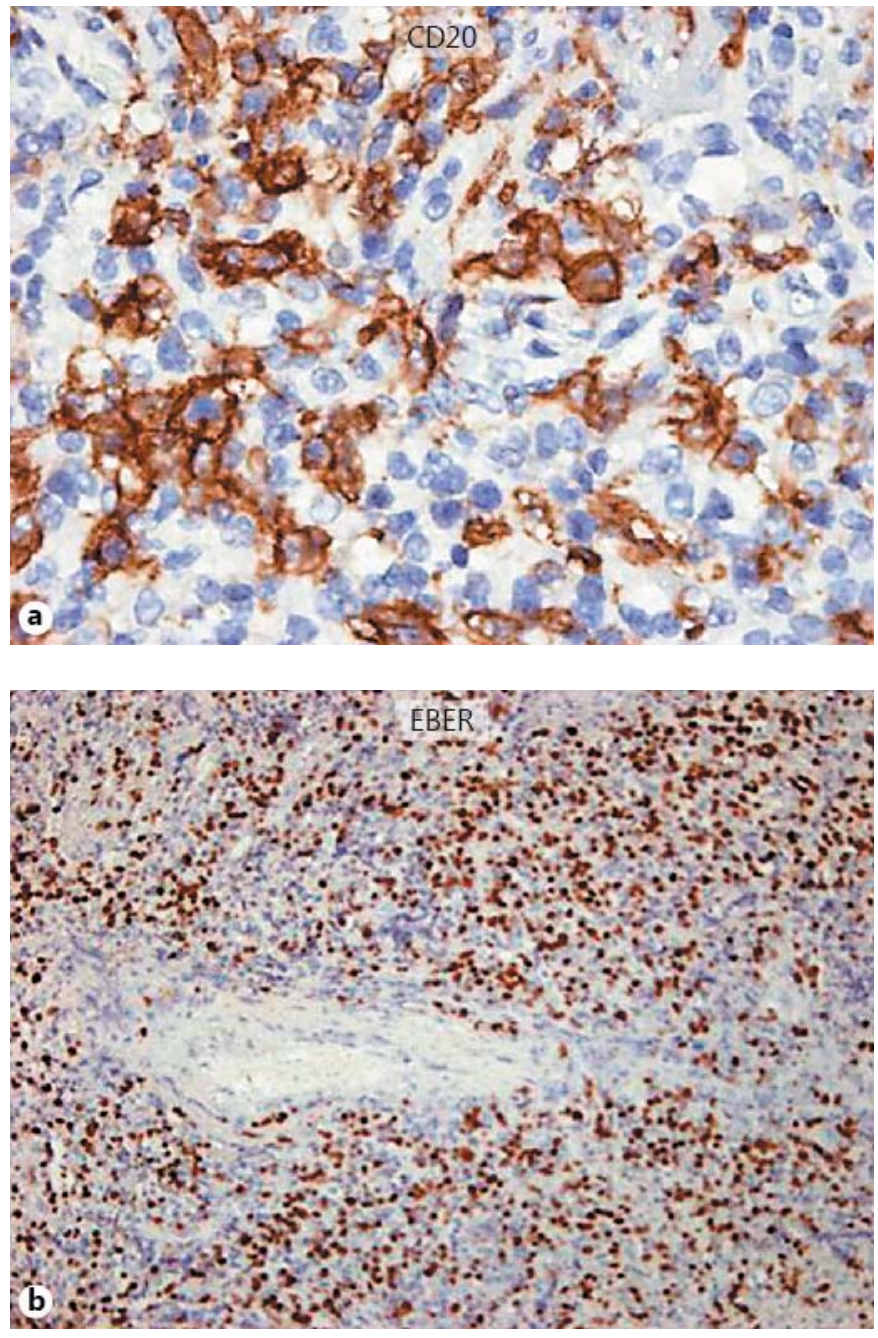

Fig. 6. Representative histology of lymphomatoid granulomatosis with positive CD20 staining (a) and positive Epstein-Barr virusencoded RNA (EBER) staining (b). Courtesy of Dr. Claire Danel, Hôpital Bichat, Paris, France.

\section{Treatment and Prognosis}

The median survival is 4 years. Causes of death in order of frequency are respiratory insufficiency (38-88\%), hemoptysis (44-89\%), neurological complications (7$31 \%)$, and infection (23-38\%) [97, 100, 107].

Factors for good prognosis are older age, no symptoms, and unilateral lung involvement, and those for poor prognosis are age $<25$ years, neurological involvement, hepatosplenomegaly, leukopenia, persistent fever, and, histologically, the number of tumoral cells and amount of necrosis $[97,100,107]$.

No therapeutic recommendations or clinical trials have been reported. Localized LG has been successfully treated with surgery or radiotherapy [110]. Steroids, rituximab, and polychemotherapy are frequently prescribed, but rituximab is inconsistently effective [111, 112]. A striking response to interferon- $\alpha$ was reported [113]. Autologous or allogeneic stem cell transplantation may be considered [114]. Spontaneous regression may be observed, particularly with grade $1 \mathrm{LG}$. The prognosis for patients not in remission is poor [100].

\section{Multicentric Castleman Disease}

\section{Human Herpesvirus 8}

HHV8 was discovered in 1994 in Kaposi sarcoma lesions and was later associated with MCD and PEL [115118]. Pulmonary manifestations of HHV8 infection occur almost exclusively in immunocompromised patients, mostly during HIV infection, and very rarely in older patients or during immunosuppressive therapy $[119,120]$.

HHV 8 has two modes of viral replication. During the latent phase, HHV8 persists in infected cells without detectable replication in the blood [121]. During the lytic phase, replication may be detected in the blood, and viral genes such as viral interleukin-6, are expressed. Most of the clinical effects of MCD are secondary to the presence of viral cytokines such as viral interleukin-6 [122124].

The reservoir of HHV8 is strictly human. The prevalence is almost $50 \%$ in sub-Saharan Africa, $30 \%$ in Sicily, and $<1 \%$ in Northern Europe and Asia [125]. In lowprevalence countries, HHV8 transmission is mostly sexual, essentially in populations with high-risk sexual behavior, with a high frequency of HIV and HHV 8 coinfection [125, 126]. In high-prevalence countries, the prevalence increases during childhood, and transmission occurs probably mostly through saliva $[127,128]$. Primary HHV8 infection is asymptomatic or results in nonspecific signs of infection and is rarely diagnosed [129].

\section{Definition}

The definition of MCD is histological: angiofollicular lymph node hyperplasia. The most frequent form is localized, occurs in nonimmunocompromised patients, and is not associated with HHV8 infection [130]. Localized MCD may take the form of a single mediastinal node (Fig. 7). As developed below, HHV8-associated MCD is clinically and histologically different from classic hyalinevascular or plasma-cell-type MCD $[116,131]$.

MCD is rare. The largest series reported were $173 \mathrm{pa-}$ tients with MCD-associated HIV infection in France, 
whereas approximately 150,000 patients are living with HIV infection in France [131-133].

\section{Clinical Presentation and Complementary Examinations}

The initial presentation of MCD may suggest lymphoma with fever, polyadenopathy, and hepatosplenomegaly. Questioning may reveal previous flares that spontaneously resolved and remained without diagnosis.

Cutaneous or mucosal localization of Kaposi sarcoma may be present in up to $75 \%$ of cases [134]. Cough, dyspnea, and expectoration are present in $33-75 \%$ of cases, but hemoptysis is rare. Nasal obstruction is frequent. Pulmonary auscultation may show crackles [132, 134, 135].

When respiratory symptoms are present, chest X-ray shows bilateral interstitial and alveolar opacities. A small pleural effusion may be present. Chest CT reveals reticular and micronodular opacities with lymphatic distribution: subpleural, peribronchovascular, or septal. Nodular or ground-glass opacities may be present. CT reveals 1- to $3-\mathrm{cm}$ mediastinal lymphadenopathies. CT findings return to normal with resolution of the flare (Fig. 7) [136].

Almost always, the C-reactive protein level is $>200$ $\mathrm{mg} / \mathrm{L}$ and anemia occurs [137]. Liver enzyme and creatinine levels may be increased. Renal insufficiency may be related to autoimmune thrombotic thrombocytopenic purpura $[138,139]$. In about $50 \%$ of cases, protein electrophoresis shows polyclonal hypergammaglobulinemia and hypoalbuminemia. Autoantibodies are present in $30 \%$ of cases: antiglobulin or anticardiolipin, antiphospholipid, or anti-ADAMTS13 antibodies [139]. CD4 counts are generally $<350 / \mathrm{mm}^{3}$.

The viral HHV 8 load as assessed by PCR is usually between 2 and $4 \log$ copies $/ 10^{5}$ peripheral blood mononuclear cells, and thus HHV8 serology is not helpful [140]. HHV8 PCR has a good negative-predictive value [121, 137]. A high HHV8 viral load may predict an MCD flare, whereas PCR results are often negative for patients in remission $[121,141,142]$.

\section{Diagnosis}

MCD is usually diagnosed by lymph node biopsy [143]. Histology shows follicular hyperplasia, hyalinization, and involution of germinal centers and hyperplasia of the mantle zone with concentric rings of lymphocytes called "onion skin" layers. Vascularity is increased, with capillary proliferation and endothelial hyperplasia. Sheets of plasma cells are present in interfollicular areas. The results of only one surgical lung biopsy have been reported, and they showed lesions similar to those in lymph nodes [136].
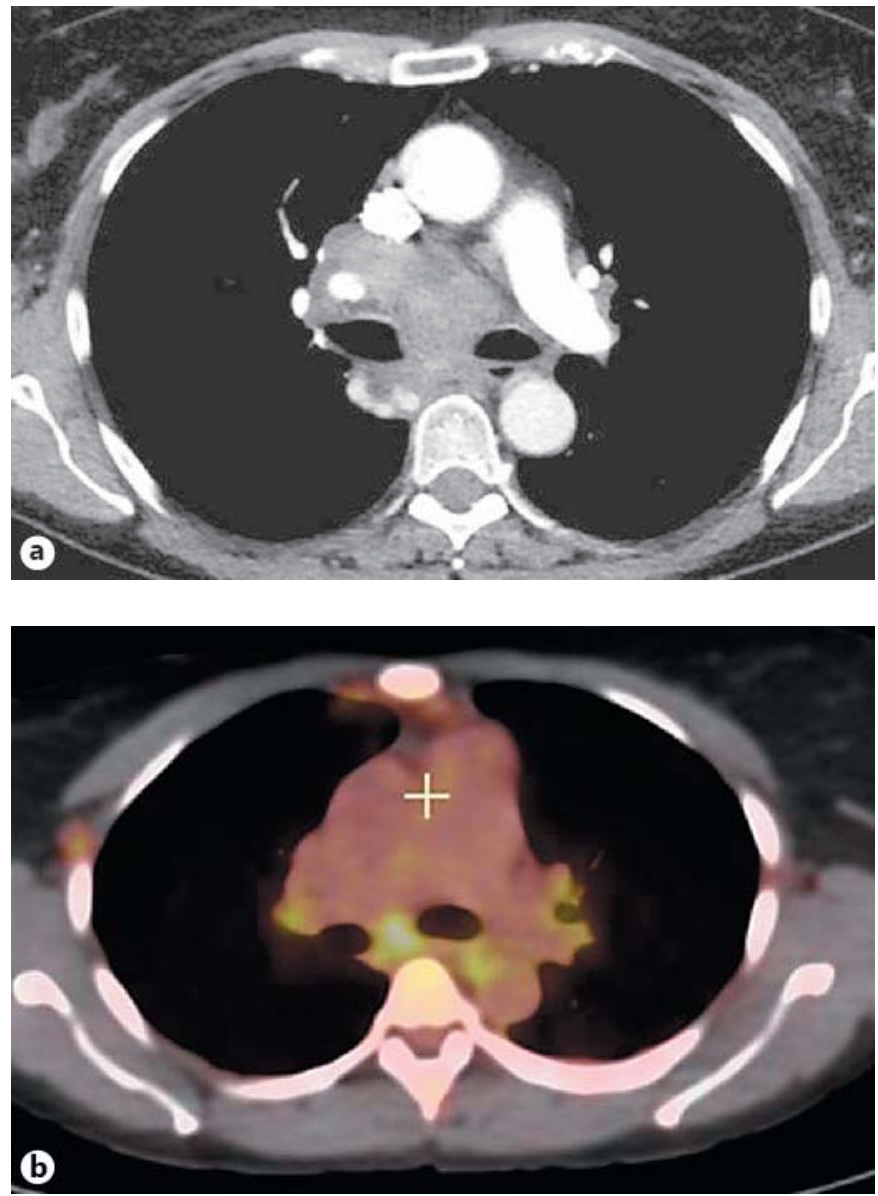

Fig. 7. a Chest CT scan of multicentric Castleman disease (MCD) with $3-\mathrm{cm}$ mediastinal (zones $4 \mathrm{R}$ and 7 ) lymphadenopathies. b Positron emission tomography CT scan of MCD with multiple peripheral and mediastinal adenopathies with FDG uptake.

HHV8-infected cells, dispersed in the mantle zone, are detected by immunohistochemistry with latent nuclear antigen antibody [144, 145]. HHV8-infected cells are not infected with EBV and are not stained with EBER. Kaposi sarcoma and MCD lesions may coexist in the same lymph node in almost two-thirds of cases [146].

HHV-8 infected cells are polyclonal, although the characterization of surface immunoglobulin shows only IgM $\lambda$ B cells [147]. B cells may group in a sheet of monoclonal cells called microlymphoma; however, the consequences of this observation remain to be determined [145].

The main differential diagnoses are tuberculosis and lymphomas, which both require a histological diagnosis. With a high HHV8 viral load, HHV8-related disease is likely and non-HHV8-related disease is unlikely. How-

Thoracic Lymphomas 
ever, an unusual evolution during therapy should suggest reconsidering the diagnosis in the absence of histological proof. During HIV infection, pulmonary manifestations of MCD should exclude infections that justify bronchoscopy with BAL fluid analysis [135]. Pleural effusion may be secondary to MCD-associated hemophagocytosis but also Kaposi sarcoma or PEL, which must be excluded by pleural fluid analysis.

A syndrome called "thrombocytopenia, anasarca including pleural effusion and ascites, fever, renal insufficiency, and organomegaly" (TAFRO) has recently been defined in Japanese patients [148]. This syndrome resembles MCD without HHV8 infection but responds to corticosteroids and tocilizumab.

\section{Prognosis and Treatment}

Median survival was reported to be $<1$ year and mortality $47 \%[134,149]$. The main reported causes of death are infections (24\%), multiple organ dysfunctions (15\%), non-Hodgkin lymphomas (15\%), and MCD (9\%). More recent series reported $>75 \% 5$-year survival partially due to the introduction of combined active antiretroviral therapy $[134,149,150]$. Although not demonstrated, delayed MCD diagnosis is probably associated with poor prognosis [134].

The risk of lymphoma, mostly related to HHV8, was previously found to be 10 - to 20 -fold increased with MCD [150]. This risk has been greatly reduced with the expanded use of rituximab and antiretroviral therapies [151].

MCD flares may spontaneously resolve, but they are likely to recur and be life-threatening without a specific therapy. Therapeutic recommendations rely on only expert opinions that propose treating (1) the HIV infection, (2) the lymphoid proliferation, and (3) the HHV8 infection $[143,152]$.

Although active against HHV8 infection in vitro, cidofovir alone has no effect on MCD. A retrospective series showed transient remission with high-dose zidovudine and valganciclovir, but only $23 \%$ long-term responders $[153,154]$.

MCD does not exhibit monoclonal lymphoid proliferation but is aggressive and lethal. The evidence supports the use of chemotherapy. Chemotherapy is urgent and induces rapid remission. Indeed, in a retrospective analysis of patients with hemophagocytosis in an intensive care unit, MCD diagnosis was associated with good prognosis [155]. Remission of MCD symptoms is achieved at about $24-48 \mathrm{~h}$ with intravenous etoposide. Etoposide may be given orally and once a week thereafter. Corticosteroids may have a partial effect on MCD flares, but they are associated with worsening of Kaposi sarcoma lesions and are not recommended [143].

However, long-term therapy with etoposide is associated with an increased risk of myelodysplasia, and alternative long-term treatment should be considered [134, 156, 157]. Although not effective as first-line therapy, rituximab led to prolonged MCD remission in almost $80 \%$ of cases [143, 149, 158-161]. With rituximab, 5-year overall survival may be $>90 \%$ [149]. However, Kaposi sarcoma worsens after rituximab injection in almost half of the cases. Prolonged remission has also been reported after polychemotherapy with $\mathrm{CHOP}$ or equivalent regimes $[134,162,163]$. Finally, some MCD experts propose etoposide as first-line therapy to control the disease and a maintenance treatment combining ganciclovir, etoposide, and rituximab, along with optimizing antiretroviral therapy $[143,152]$.

\section{Primary Effusion Lymphoma}

\section{Definition}

PEL involves the pleura, pericardium, or peritoneum in immunocompromised patients. PEL is distinguished from solid lymphoma with secondary effusion localization $[109,117]$. However, PEL has also been described in a solid form - called extracavitary PEL - that may occur as a relapse of classic PEL or as an initial presentation $[164,165]$. PEL is a rare lymphoma corresponding to $0.5 \%$ of all lymphoma cases and $1-8 \%$ of HIV-associated non-Hodgkin lymphoma cases [165-167].

\section{Clinical Presentation and Complementary \\ Examinations}

Patients mostly present with fever, altered performance status, and dyspnea [168]. Pleural effusion is present in $85 \%$ of cases and is associated with ascites in $50 \%$ of cases [169]. PEL may also provoke a specific pericardial localization with a risk of secondary cardiac tamponade [168]. Hepatomegaly and splenomegaly are present in twothirds of cases [168]. Cutaneous or mucosal localization of Kaposi sarcoma is present in $25-100 \%$ of cases, and 9-50\% of patients present with concomitant MCD. However, enlarged peripheral lymph nodes are rare. Neurological deficit or a maxillary lesion should lead to suspicion of the specific localization of extracavitary PEL [169].

Anemia is frequent and is associated in $50 \%$ of cases with thrombocytopenia and hypoalbuminemia [169]. LDH levels are frequently elevated [168]. The mean CD4 count is $150-200 / \mathrm{mm}^{3}$ [168].
Borie/Wislez/Antoine/Cadranel 


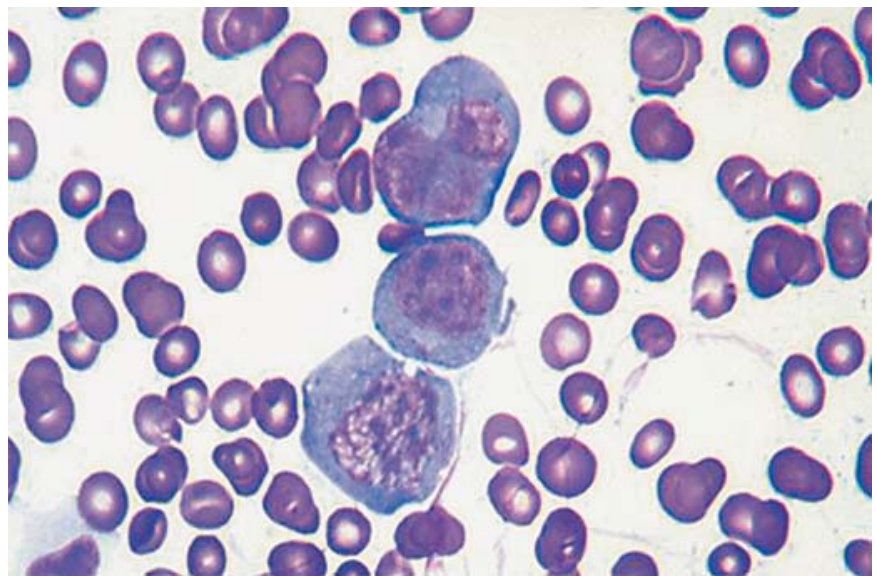

Fig. 8. Cytology of a primary effusion lymphoma confirmed by latent nuclear antigen staining and human herpesvirus 8 PCR. Courtesy of Dr. Claire Danel, Hôpital Bichat, Paris, France.

Bone marrow biopsy may show hemophagocytosis, but only rarely tumor cells $[168,169]$. CT reveals pleural effusion without pulmonary lesions or a detectable mass. A small pleural thickening may be present. Pericardial or peritoneal effusion may occur [170]. Pleural fluid analysis, mandatory for a diagnosis, shows serohematic exudative fluid [168].

\section{Diagnosis}

Diagnosis is by cytologic examination of the pleural fluid. Pleural biopsy is generally not required or helpful. Cells are polymorphous and large, sometimes immunoblastic, with some plasma cell differentiation and irregular polylobular nuclei (Fig. 8). Cytoplasm is abundant and hyperbasophilic. Mitoses are numerous. Cells generally do not express B-cell markers (CD19 or CD20) or T-cell markers (CD3) but do express CD45, which confirms the lymphoid origin, and may express aberrant T-cell markers such as intracytoplasmic CD3 or CD4. They may coexpress activation markers (CD30, CD38, CD71, or MUM1) and plasma cell markers (CD138) [171, 172]. The $\mathrm{B}$ cells are monoclonal, but clonality analysis is not helpful for the diagnosis [173].

In contrast, HHV8 infection must be confirmed by immunohistochemistry with latent nuclear antigen staining on tumor cells or PCR evaluation of the viral load in pleural fluid. In blood, the HHV8 viral load is generally $>4 \mathrm{log}$ copies $/ 10^{5}$ peripheral blood mononuclear cells, and there is a 3:4 log ratio between pleura and blood [121, 140].

In $70 \%$ of cases, tumor cells are coinfected with EBV. However, immunostaining with latent membrane pro-

Thoracic Lymphomas tein is negative, whereas EBER staining or PCR analysis of the pleural fluid is positive [169]. Cytogenetic analysis shows a complex karyotype without common or recurrent chromosomal abnormality [174].

Detection of HHV8 is helpful to differentiate PEL from other lymphomas $[175,176]$. Pleural effusion with fever in an immunocompromised patient is more often secondary to Kaposi sarcoma or an infectious disease such as tuberculosis than due to PEL. In these cases, pleural fluid analysis does not reveal tumor cells, and HHV8 PCR findings in pleural fluid are negative or weak.

\section{Prognosis and Treatment}

No recommended therapy for PEL exists. Median survival is $<1$ year, with a $39 \% 1$-year survival [169]. Absence of antiretroviral therapy at diagnosis is associated with poor prognosis, and optimized antiretroviral therapy alone can have antitumoral activity and may lead to remission $[169,177]$. The number and type of involved cavities could be associated with median survival [178]. However, a retrospective single-center study did not find any statistical difference between patients with involvement of only one cavity and those with involvement of more than one cavity [165]. LDH level and CD4 positivity may be prognostic factors [179].

Polychemotherapy such as $\mathrm{CHOP}$ with or without methotrexate is most often prescribed. Although associated with high morbidity, the treatment may result in complete remission in up to $61 \%$ of cases $[169,180]$. Rituximab should not be prescribed, because tumor cells do not express CD20 and rituximab increases the immunodeficiency. Bortezomib has been investigated, and rapamycin, anti-vascular endothelial growth factor therapy, or interferon has been found to be effective in anecdotal cases $[169,181,182]$. Pleurodesis with talc or intrapleural cidofovir may be discussed in palliative situations $[183,184]$.

\section{Conclusions}

In lymphoproliferative disorders, lung involvement can be widespread, is varied, and may be of concern to lung specialists. Unfortunately, the rarity of these diseases frequently leads to delays in diagnosis or unnecessary examinations. The first step always is to make an assessment of the background: whether or not immunodeficiency is involved, and whether or not it is an autoimmune disease. The second step is to evaluate the presence of general signs that then require a rapid diagnosis.

Respiration 2017;94:157-175 169 
However, minimally invasive procedures (such as pleural fluid analysis and transbronchial biopsy) with specialized and oriented analysis (immunohistochemistry and molecular biological techniques) most frequently allow for a diagnosis. Finally, there are neither clinical tri- als nor recommendations on pulmonary lymphoproliferative disorders, and treatment is based on expert opinion, which justifies seeking advice from a specialized center.

\section{References}

1 Isaacson PG, Norton AJ: Extranodal Lymphomas. New York, Churchill Livingstone, 1994.

2 Freeman C, Berg JW, Cutler SJ: Occurrence and prognosis of extranodal lymphomas. Cancer 1972;29:252-260.

3 Jaffe E, Travis W: Lymphomatoid Granulomatosis and Lymphoproliferative Disorders of the Lung. Philadelphia, Lippincott, 1991.

4 Harris NL, Jaffe ES, Stein H, Banks PM, Chan JK, Cleary ML, Delsol G, De Wolf-Peeters C, Falini B, Gatter KC, et al: A revised EuropeanAmerican classification of lymphoid neoplasms: a proposal from the International Lymphoma Study Group. Blood 1994;84: 1361-1392.

5 Nathwani BN, Anderson JR, Armitage JO, Cavalli F, Diebold J, Drachenberg MR, Harris NL, MacLennan KA, Müller-Hermelink HK, Ullrich FA, Weisenburger DD: Marginal zone B-cell lymphoma: a clinical comparison of nodal and mucosa-associated lymphoid tissue types. Non-Hodgkin's Lymphoma Classification Project. J Clin Oncol 1999;17:24862492.

6 Remstein ED, James CD, Kurtin PJ: Incidence and subtype specificity of API2-MALT1 fusion translocations in extranodal, nodal, and splenic marginal zone lymphomas. Am J Pathol 2000;156:1183-1188.

7 Campo E, Miquel R, Krenacs L, Sorbara L, Raffeld M, Jaffe ES: Primary nodal marginal zone lymphomas of splenic and MALT type. Am J Pathol 1999;23:59-68.

8 Campo E, Swerdlow SH, Harris NL, Pileri S, Stein H, Jaffe ES: The 2008 WHO classification of lymphoid neoplasms and beyond: evolving concepts and practical applications. Blood 2011;117:5019-5032.

9 A clinical evaluation of the International Lymphoma Study Group classification of non-Hodgkin's lymphoma. The Non-Hodgkin's Lymphoma Classification Project. Blood 1997;89:3909-3918.

10 Suarez F, Lortholary O, Hermine O, Lecuit M: Infection-associated lymphomas derived from marginal zone B cells: a model of antigen-driven lymphoproliferation. Blood 2006; 107:3034-3044.

11 Borie R, Cadranel J, Guihot A, Marcelin AG, Galicier L, Couderc LJ: Pulmonary manifestations of human herpesvirus- 8 during HIV infection. Eur Respir J 2013;42:1105-1118.
12 Amedei A, Bergman MP, Appelmelk BJ, Azzurri A, Benagiano $M$, Tamburini $C$, van der Zee R, Telford JL, Vandenbroucke-Grauls CM, D’Elios MM, Del Prete G: Molecular mimicry between Helicobacter pylori antigens and $\mathrm{H}^{+}, \mathrm{K}^{+}$-adenosine triphosphatase in human gastric autoimmunity. J Exp Med 2003; 198:1147-1156.

13 Parsonnet J, Hansen S, Rodriguez L, Gelb AB, Warnke RA, Jellum E, Orentreich N, Vogelman JH, Friedman GD: Helicobacter pylori infection and gastric lymphoma. N Engl J Med 1994;330:1267-1271.

14 Raderer M, Wöhrer S, Kiesewetter B, Dolak W, Lagler H, Wotherspoon A, Muellauer L, Chott A: Antibiotic treatment as sole management of Helicobacter pylori-negative gastric MALT lymphoma: a single center experience with prolonged follow-up. Ann Hematol 2015;94:969-973.

15 Bertoni F, Zucca E: State-of-the-art therapeutics: marginal-zone lymphoma. J Clin Oncol 2005;23:6415-6420.

16 Ferry JA: Extranodal lymphoma. Arch Pathol Lab Med 2008;132:565-578.

17 Chanudet E, Zhou Y, Bacon CM, Wotherspoon AC, Müller-Hermelink HK, Adam P, Dong HY, de Jong D, Li Y, Wei R, Gong X, Wu Q, Ranaldi R, Goteri G, Pileri SA, Ye H, Hamoudi RA, Liu H, Radford J, Du MQ: Chlamydia psittaci is variably associated with ocular adnexal MALT lymphoma in different geographical regions. J Pathol 2006;209:344351.

18 Catherinot E, Longchampt E, Ferroni A, Rivaud E, Cahen P, Couderc LJ: Pulmonary mucosa-associated lymphoid tissue lymphoma revisited. Eur Respir J 2016;48:1250-1251.

19 Adam P, Czapiewski P, Colak S, Kosmidis P, Tousseyn T, Sagaert X, Boudova L, Okoń K, Morresi-Hauf A, Agostinelli C, Pileri S, Pruneri G, Martinelli G, Du MQ, Fend F: Prevalence of Achromobacter xylosoxidans in pulmonary mucosa-associated lymphoid tissue lymphoma in different regions of Europe. $\mathrm{Br}$ J Haematol 2014;164:804-810.

20 Foulongne V, Sauvage V, Hebert C, Dereure O, Cheval J, Gouilh MA, Pariente K, Segondy $\mathrm{M}$, Burguière A, Manuguerra JC, Caro V, Eloit M: Human skin microbiota: high diversity of DNA viruses identified on the human skin by high throughput sequencing. PLoS One 2012;7:e38499.
21 Lecuit M, Eloit M: The diagnosis of infectious diseases by whole genome next generation sequencing: a new era is opening. Front Cell Infect Microbiol 2014;4:25.

22 Ekström Smedby K, Vajdic CM, Falster M, Engels EA, Martínez-Maza O, Turner J, Hjalgrim H, Vineis $\mathrm{P}$, Seniori Costantini A, Bracci PM, Holly EA, Willett E, Spinelli JJ, La Vecchia C, Zheng T, Becker N, de Sanjosé S, Chiu BC, Dal Maso L, Cocco P, Maynadié M, Foretova L, Staines A, Brennan P, Davis S, Severson R, Cerhan JR, Breen EC, Birmann B, Grulich AE, Cozen W: Autoimmune disorders and risk of non-Hodgkin lymphoma subtypes: a pooled analysis within the InterLymph Consortium. Blood 2008;111:40294038.

23 Bracci PM, Benavente Y, Turner JJ, Paltiel O, Slager SL, Vajdic CM, Norman AD, Cerhan JR, Chiu BC, Becker N, Cocco P, Dogan A, Nieters A, Holly EA, Kane EV, Smedby KE, Maynadié M, Spinelli JJ, Roman E, Glimelius B, Wang SS, Sampson JN, Morton LM, de Sanjosé S: Medical history, lifestyle, family history, and occupational risk factors for marginal zone lymphoma: the InterLymph NonHodgkin Lymphoma Subtypes Project. J Natl Cancer Inst Monogr 2014;2014:52-65.

24 Kurtin PJ, Myers JL, Adlakha H, Strickler JG, Lohse C, Pankratz VS, Inwards DJ: Pathologic and clinical features of primary pulmonary extranodal marginal zone B-cell lymphoma of MALT type. Am J Surg Pathol 2001;25:9971008.

25 Li G, Hansmann ML, Zwingers T, Lennert K: Primary lymphomas of the lung: morphological, immunohistochemical and clinical features. Histopathology 1990;16:519-531.

26 Borie R, Wislez M, Thabut G, Antoine M, Rabbat A, Couderc LJ, Monnet I, Nunes H, Blanc FX, Mal H, Bergeron A, Dusser D, Israël-Biet D, Crestani B, Cadranel J: Clinical characteristics and prognostic factors of pulmonary MALT lymphoma. Eur Respir J 2009; 34:1408-1416.

27 Cadranel J, Wislez M, Antoine M: Primary pulmonary lymphoma. Eur Respir J 2002;20: 750-762.

28 Cordier JF, Chailleux E, Lauque D, ReynaudGaubert M, Dietemann-Molard A, Dalphin JC, Blanc-Jouvan F, Loire R: Primary pulmonary lymphomas. A clinical study of 70 cases in nonimmunocompromised patients. Chest 1993;103:201-208. 
29 Herbert A, Wright DH, Isaacson PG, Smith JL: Primary malignant lymphoma of the lung: histopathologic and immunologic evaluation of nine cases. Hum Pathol 1984;15:415-422.

30 Kennedy JL, Nathwani BN, Burke JS, Hill LR, Rappaport H: Pulmonary lymphomas and other pulmonary lymphoid lesions. A clinicopathologic and immunologic study of 64 patients. Cancer 1985;56:539-552.

31 Le Tourneau A, Audouin J, Garbe L, Capron F, Servais B, Monges G, Payan H, Diebold J: Primary pulmonary malignant lymphoma, clinical and pathological findings, immunocytochemical and ultrastructural studies in 15 cases. Hematol Oncol 1983;1:49-60.

32 L'Hoste RJ Jr, Filippa DA, Lieberman PH, Bretsky S: Primary pulmonary lymphomas. A clinicopathologic analysis of 36 cases. Cancer 1984;54:1397-1406.

33 Lee DK, Im JG, Lee KS, Lee JS, Seo JB, Goo JM, Kim TS, Lee JW: B-cell lymphoma of bronchus-associated lymphoid tissue (BALT): CT features in 10 patients. J Comput Assist Tomogr 2000;24:30-34.

34 Wislez M, Cadranel J, Antoine M, Milleron B, Bazot M, Mayaud C, Carette MF: Lymphoma of pulmonary mucosa-associated lymphoid tissue: CT scan findings and pathological correlations. Eur Respir J 1999;14:423-429.

35 Thieblemont C, Bastion Y, Berger F, Rieux C, Salles G, Dumontet C, Felman P, Coiffier B: Mucosa-associated lymphoid tissue gastrointestinal and nongastrointestinal lymphoma behavior: analysis of 108 patients. J Clin Oncol 1997;15:1624-1630.

36 Thieblemont C, Berger F, Dumontet C, Moullet I, Bouafia F, Felman P, Salles G, Coiffier B: Mucosa-associated lymphoid tissue lymphoma is a disseminated disease in one third of 158 patients analyzed. Blood 2000;95:802-806.

37 Zinzani PL, Magagnoli M, Galieni P, Martelli M, Poletti V, Zaja F, Molica S, Zaccaria A, Cantonetti AM, Gentilini P, Guardigni L, Gherlinzoni F, Ribersani M, Bendandi M, Albertini P, Tura S: Nongastrointestinal lowgrade mucosa-associated lymphoid tissue lymphoma: analysis of 75 patients. J Clin Oncol 1999;17:1254.

38 Raderer M, Vorbeck F, Formanek M, Österreicher C, Valencak J, Penz M, Kornek G, Hamilton G, Dragosics B, Chott A: Importance of extensive staging in patients with mucosa-associated lymphoid tissue (MALT)type lymphoma. Br J Cancer 2000;83:454457.

39 Enomoto K, Hamada K, Inohara H, Higuchi I, Tomita Y, Kubo T, Hatazawa J: Mucosaassociated lymphoid tissue lymphoma studied with FDG-PET: a comparison with CT and endoscopic findings. Ann Nucl Med 2008;22: 261-267.

40 Beal KP, Yeung HW, Yahalom J: FDG-PET scanning for detection and staging of extranodal marginal zone lymphomas of the MALT type: a report of 42 cases. Ann Oncol 2005;16: 473-480.
41 Bae YA, Lee KS, Han J, Ko YH, Kim BT, Chung MJ, Kim TS: Marginal zone B-cell lymphoma of bronchus-associated lymphoid tissue: imaging findings in 21 patients. Chest 2008;133:433-440.

42 Hoffmann M, Wöhrer S, Becherer A, Chott A, Streubel B, Kletter K, Raderer M: ${ }^{18} \mathrm{~F}$-fluorodeoxy-glucose positron emission tomography in lymphoma of mucosa-associated lymphoid tissue: histology makes the difference. Ann Oncol 2006; 17:1761-1765.

43 Drent M, Wagenaar SS, Mulder PH, van Velzen-Blad H, Diamant M, van den Bosch JM: Bronchoalveolar lavage fluid profiles in sarcoidosis, tuberculosis, and non-Hodgkin's and Hodgkin's disease. An evaluation of differences. Chest 1994;105:514-519.

44 Costabel U, Bross KJ, Matthys H: Diagnosis by bronchoalveolar lavage of cause of pulmonary infiltrates in haematological malignancies. Br Med J (Clin Res Ed) 1985;290:1041.

45 Pisani RJ, Witzig TE, Li CY, Morris MA, Thibodeau SN: Confirmation of lymphomatous pulmonary involvement by immunophenotypic and gene rearrangement analysis of bronchoalveolar lavage fluid. Mayo Clin Proc 1990;65:651-656.

46 Schwaiger A, Prior C, Weyrer K, Umlauft F, Gattringer C, Grünewald K, Tötsch M, Fend F: Non-Hodgkin's lymphoma of the lung diagnosed by gene rearrangement from bronchoalveolar lavage fluid: a fast and noninvasive method. Blood 1991;77:2538-2539.

47 Shiota T, Chiba W, Ikeda S, Ikei N: Gene analysis of pulmonary pseudolymphoma. Chest 1993;103:335-338.

48 Subramanian D, Albrecht S, Gonzalez JM, Cagle PT: Primary pulmonary lymphoma. Diagnosis by immunoglobulin gene rearrangement study using a novel polymerase chain reaction technique. Am Rev Respir Dis 1993;148:222-226.

49 Zompi S, Couderc LJ, Cadranel J, Antoine M, Epardeau B, Fleury-Feith J, Popa N, Santoli F, Farcet JP, Delfau-Larue MH: Clonality analysis of alveolar B lymphocytes contributes to the diagnostic strategy in clinical suspicion of pulmonary lymphoma. Blood 2004;103: 3208-3215.

50 Kido T, Yatera K, Noguchi S, Sakurai Y, Nagata S, Kozaki M, Tokuyama S, Ogoshi T, Kawanami T, Yoshii C, Mukae H: Detection of MALT1 gene rearrangements in BAL fluid cells for the diagnosis of pulmonary mucosaassociated lymphoid tissue lymphoma. Chest 2012;141:176-182.

51 Borie R, Wislez M, Antoine M, Fleury-Feith J, Thabut G, Crestani B, Monnet I, Nunes H, Delfau-Larue MH, Cadranel J: Clonality and phenotyping analysis of alveolar lymphocytes is suggestive of pulmonary MALT lymphoma. Respir Med 2011;105:1231-1237.
52 Nunez AL, Jhala NC, Carroll AJ, Mikhail FM, Reddy VV, Xian RR, Jhala DN: Endoscopic ultrasound and endobronchial ultrasoundguided fine-needle aspiration of deep-seated lymphadenopathy: analysis of 1,338 cases. Cytojournal 2012;9:14.

53 Poletti V, Gurioli C, Piciucchi S, Rossi A, Ravaglia C, Dubini A, Asioli S, Casoni GL: Intravascular large B cell lymphoma presenting in the lung: the diagnostic value of transbronchial cryobiopsy. Sarcoidosis Vasc Diffuse Lung Dis 2015;31:354-358.

54 Addis BJ, Hyjek E, Isaacson PG: Primary pulmonary lymphoma: a re-appraisal of its histogenesis and its relationship to pseudolymphoma and lymphoid interstitial pneumonia. Histopathology 1988;13:1-17.

55 Nicholson AG, Wotherspoon AC, Diss TC, Butcher DN, Sheppard MN, Isaacson PG, Corrin B: Pulmonary B-cell non-Hodgkin's lymphomas. The value of immunohistochemistry and gene analysis in diagnosis. Histopathology 1995;26:395-403.

56 Bégueret H, Vergier B, Parrens M, Lehours P, Laurent F, Vernejoux JM, Dubus P, Velly JF, Mégraud F, Taytard A, Merlio JP, de Mascarel A: Primary lung small B-cell lymphoma versus lymphoid hyperplasia: evaluation of diagnostic criteria in 26 cases. Am J Surg Pathol 2002;26:76-81.

57 Fiche M, Caprons F, Berger F, Galateau F, Cordier JF, Loire R, Diebold J: Primary pulmonary non-Hodgkin's lymphomas. Histopathology 1995;26:529-537.

58 Turner RR, Colby TV, Doggett RS: Well-differentiated lymphocytic lymphoma. A study of 47 patients with primary manifestation in the lung. Cancer 1984;54:2088-2096.

59 Koss MN, Hochholzer L, Nichols PW, Wehunt WD, Lazarus AA: Primary non-Hodgkin's lymphoma and pseudolymphoma of lung: a study of 161 patients. Hum Pathol 1983;14:1024-1038.

60 Foulet A, Petrella T, Viard H, Jeannin L, Drouot F, Arnould L, Justrabo E, Michiels R: Lympho-epithelial lesions induced by plasma cells in a pulmonary MALT lymphoma (in French). Ann Pathol 1994;14:36-40.

61 Peterson H, Snider HL, Yam LT, Bowlds CF, Arnn EH, Li CY: Primary pulmonary lymphoma. A clinical and immunohistochemical study of six cases. Cancer 1985;56:805-813.

62 Abbondanzo SL, Rush W, Bijwaard KE, Koss MN: Nodular lymphoid hyperplasia of the lung: a clinicopathologic study of 14 cases. Am J Surg Pathol 2000;24:587-597.

63 Remstein ED, Dogan A, Einerson RR, Paternoster SF, Fink SR, Law M, Dewald GW, Kurtin PJ: The incidence and anatomic site specificity of chromosomal translocations in primary extranodal marginal zone B-cell lymphoma of mucosa-associated lymphoid tissue (MALT lymphoma) in North America. Am J Surg Pathol 2006;30:1546-1553. 
64 Farinha P, Gascoyne RD: Molecular pathogenesis of mucosa-associated lymphoid tissue lymphoma. J Clin Oncol 2005;23:6370-6378.

65 Streubel B, Simonitsch-Klupp I, Müllauer L, Lamprecht A, Huber D, Siebert R, Stolte M, Trautinger F, Lukas J, Püspök A, Formanek M, Assanasen T, Müller-Hermelink HK, Cerroni L, Raderer M, Chott A: Variable frequencies of MALT lymphoma-associated genetic aberrations in MALT lymphomas of different sites. Leukemia 2004;18:1722-1726.

66 Li Z, Wang H, Xue L, Shin DM, Roopenian D, Xu W, Qi CF, Sangster MY, Orihuela CJ, Tuomanen E, Rehg JE, Cui X, Zhang Q, Morse HC 3rd, Morris SW: E $\mu$-BCL10 mice exhibit constitutive activation of both canonical and noncanonical NF- $\mathrm{KB}$ pathways generating marginal zone (MZ) B-cell expansion as a precursor to splenic MZ lymphoma. Blood 2009; 114:4158-4168.

67 Sagaert X, Theys T, De Wolf-Peeters C, Marynen P, Baens M: Splenic marginal zone lymphoma-like features in API2-MALT1 transgenic mice that are exposed to antigenic stimulation. Haematologica 2006;91:16931696.

68 Baens M, Fevery S, Sagaert X, Noels H, Hagens S, Broeckx V, Billiau AD, De WolfPeeters C, Marynen P: Selective expansion of marginal zone $\mathrm{B}$ cells in E $\mu$-API2-MALT1 mice is linked to enhanced IкB kinase $\gamma$ polyubiquitination. Cancer Res 2006;66:52705277.

69 Dreyling M, Thieblemont C, Gallamini A, Arcaini L, Campo E, Hermine O, Kluin-Nelemans JC, Ladetto M, Le Gouill S, Iannitto E, Pileri S, Rodriguez J, Schmitz N, Wotherspoon A, Zinzani P, Zucca E: ESMO Consensus conferences: guidelines on malignant lymphoma. Part 2: marginal zone lymphoma, mantle cell lymphoma, peripheral T-cell lymphoma. Ann Oncol 2013;24:857-877.

70 Zucca E, Stathis A, Bertoni F: The management of nongastric MALT lymphomas. Oncology (Williston Park) 2014;28:86-93.

71 Wöhrer S, Kiesewetter B, Fischbach J, Müllauer L, Troch M, Lukas J, Mayerhoefer ME, Raderer M: Retrospective comparison of the effectiveness of various treatment modalities of extragastric MALT lymphoma: a singlecenter analysis. Ann Hematol 2014;93:12871295.

72 Girinsky T, Paumier A, Ferme C, Hanna C, Ribrag V, Leroy-Ladurie F, Ghalibafian M: Low-dose radiation treatment in pulmonary mucosa-associated lymphoid tissue lymphoma: a plausible approach? A single-institution experience in 10 patients. Int J Radiat Oncol Biol Phys 2012;83:e385-e389.

73 Wang L, Xia ZJ, Zhang YJ, Huang HQ, Lin TY, Lu Y: Radical surgery may be not an optimal treatment approach for pulmonary MALT lymphoma. Tumour Biol 2015;36: 6409-6416.
74 Nakamura S, Sugiyama T, Matsumoto T, Iijima K, Ono S, Tajika M, Tari A, Kitadai Y, Matsumoto $H$, Nagaya $T$, Kamoshida $T$, Watanabe N, Chiba T, Origasa $\mathrm{H}$, Asaka M; JAPAN GAST Study Group: Long-term clinical outcome of gastric MALT lymphoma after eradication of Helicobacter pylori: a multicentre cohort follow-up study of 420 patients in Japan. Gut 2012;61:507-513.

75 Conconi A, Martinelli G, Thieblemont C, Ferreri AJ, Devizzi L, Peccatori F, Ponzoni M, Pedrinis E, Dell'Oro S, Pruneri G, Filipazzi V, Dietrich PY, Gianni AM, Coiffier B, Cavalli F, Zucca E: Clinical activity of rituximab in extranodal marginal zone B-cell lymphoma of MALT type. Blood 2003;102:2741-2745.

76 Zucca E, Conconi A, Laszlo D, López-Guillermo A, Bouabdallah R, Coiffier B, Sebban C, Jardin F, Vitolo U, Morschhauser F, Pileri SA, Copie-Bergman C, Campo E, Jack A, Floriani I, Johnson P, Martelli M, Cavalli F, Martinelli G, Thieblemont C: Addition of rituximab to chlorambucil produces superior event-free survival in the treatment of patients with extranodal marginal-zone B-cell lymphoma: 5-year analysis of the IELSG-19 randomized study. J Clin Oncol 2013;31: 565-572.

77 Lévy M, Copie-Bergman C, Amiot A, Dupuis J, Baleur YL, Belhadj K, Hémery F, Sobhani I, Delfau-Larue MH, Leroy K, Haioun C, Delchier JC: Rituximab and chlorambucil versus rituximab alone in gastric mucosa-associated lymphoid tissue lymphoma according to $t(11$; 18) status: a monocentric non-randomized observational study. Leuk Lymphoma 2013; 54:940-944.

78 Amiot A, Lévy M, Copie-Bergman C, Dupuis J, Szablewski V, Le Baleur Y, Baia M, Belhadj K, Sobhani I, Leroy K, Haioun C, Delchier JC: Rituximab, alkylating agents or combination therapy for gastric mucosa-associated lymphoid tissue lymphoma: a monocentric nonrandomised observational study. Aliment Pharmacol Ther 2014;39:619-628.

79 Zinzani PL, Stefoni V, Musuraca G, Tani M, Alinari L, Gabriele A, Marchi E, Pileri S, Baccarani M: Fludarabine-containing chemotherapy as frontline treatment of nongastrointestinal mucosa-associated lymphoid tissue lymphoma. Cancer 2004;100:2190-2194.

80 Wöhrer S, Drach J, Hejna M, Scheithauer W, Dirisamer A, Püspök A, Chott A, Raderer M: Treatment of extranodal marginal zone B-cell lymphoma of mucosa-associated lymphoid tissue (MALT lymphoma) with mitoxantrone, chlorambucil and prednisone (MCP). Ann Oncol 2003; 14:1758-1761.

81 Salar A, Domingo-Domenech E, Estany C, Canales MA, Gallardo F, Servitje O, Fraile G, Montalbán C: Combination therapy with rituximab and intravenous or oral fludarabine in the first-line, systemic treatment of patients with extranodal marginal zone B-cell lymphoma of the mucosa-associated lymphoid tissue type. Cancer 2009;115:52105217.
82 Salar A, Avivi I, Bittner B, Bouabdallah R, Brewster M, Catalani O, Follows G, Haynes A, Hourcade-Potelleret F, Janikova A, Larouche JF, McIntyre C, Pedersen M, Pereira J, Sayyed P, Shpilberg O, Tumyan G: Comparison of subcutaneous versus intravenous administration of rituximab as maintenance treatment for follicular lymphoma: results from a twostage, phase IB study. J Clin Oncol 2014;32: 1782-1791.

83 Troch M, Kiesewetter B, Willenbacher W, Willenbacher E, Zebisch A, Linkesch W, Fridrik M, Müllauer L, Greil R, Raderer M: Rituximab plus subcutaneous cladribine in patients with extranodal marginal zone B-cell lymphoma of mucosa-associated lymphoid tissue: a phase II study by the Arbeitsgemeinschaft Medikamentöse Tumortherapie. Haematologica 2013;98:264-268.

84 Troch M, Jonak C, Müllauer L, Püspök A, Formanek M, Hauff W, Zielinski CC, Chott A, Raderer M: A phase II study of bortezomib in patients with MALT lymphoma. Haematologica 2009;94:738-742.

85 Kiesewetter B, Troch M, Dolak W, Müllauer L, Lukas J, Zielinski CC, Raderer M: A phase II study of lenalidomide in patients with extranodal marginal zone B-cell lymphoma of the mucosa associated lymphoid tissue (MALT lymphoma). Haematologica 2013;98: 353-356.

86 Jäger G, Höfler G, Linkesch W, Neumeister P: Occurrence of a myelodysplastic syndrome (MDS) during first-line 2-chloro-deoxyadenosine (2-CDA) treatment of a low-grade gastrointestinal MALT lymphoma. Case report and review of the literature. Haematologica 2004;89:ECR01.

87 Thieblemont C, Molina T, Davi F: Optimizing therapy for nodal marginal zone lymphoma. Blood 2016;127:2064-2071.

88 Stefanovic A, Morgensztern D, Fong T, Lossos IS: Pulmonary marginal zone lymphoma: a single centre experience and review of the SEER database. Leuk Lymphoma 2008;49: 1311-1320.

89 Zucca E, Conconi A, Pedrinis E, Cortelazzo S, Motta T, Gospodarowicz MK, Patterson BJ, Ferreri AJ, Ponzoni M, Devizzi L, Giardini R, Pinotti G, Capella C, Zinzani PL, Pileri S, López-Guillermo A, Campo E, Ambrosetti A, Baldini L, Cavalli F; International Extranodal Lymphoma Study Group: Nongastric marginal zone B-cell lymphoma of mucosa-associated lymphoid tissue. Blood 2003;101:2489-2495.

90 Thieblemont C, Conconi A, Laszlo D, Tucci A, Vitolo U, Martelli M, Morschhauser F, Ghesquieres $H$, Pettengell R, Pinotti G, Devizzi L, Bouabdallah R, Lopez-Guillermo A, Ferreri AJ, Pileri S, Traverse-Glehen A, Jack A, Campo E, Mazzucchelli L, Cascione L, Johnson PW, Coiffer B, Martinelli G, Cavalli F, Zucca A: A simple and effective MALT lymphoma-specific prognostic index generated from the dataset of the IELSG-19 controlled clinical trial. Hematol Oncol 2015;33: 167-168. 
91 Hadjadj J, Malphettes M, Fieschi C, Oksenhendler E, Tazi A, Bergeron A: Lung disease in adult common variable immunodeficiency (in French). Rev Mal Respir 2015;32:9911001.

92 Kawahara K, Shiraishi T, Okabayashi K, Iwasaki A, Hayashi K, Matsuo T, Mita S, Maekawa T, Shirakusa T, Kikuti M, Tashiro K: Nodular lymphoid hyperplasia in the lung. Thorac Cardiovasc Surg 1996;44:210-212.

93 Nakamura H, Miwa K, Haruki T, Adachi Y, Fujioka S, Taniguchi Y: Multifocal nodular lymphoid hyperplasia of the lung differently identified by ${ }^{18} \mathrm{~F}$-fluorodeoxyglucose positron emission tomography (FDG-PET). Thorac Cardiovasc Surg 2009;57:439-440.

94 Saltzstein SL: Pulmonary malignant lymphomas and pseudolymphomas: classification, therapy, and prognosis. Cancer 1963; 16:928-955.

95 Bois MC, Sekiguchi H, Ryu JH, Yi ES: No definite clinical features of IgG4-related disease in patients with pulmonary nodular lymphoid hyperplasia. Hum Pathol 2017; 59:80-86.

96 Kajiwara S, Sakai S, Soeda H, Takahashi N, Okafuji T, Yoshimitsu K, Yabuuchi H, Yoshino I, Honda H: Multifocal nodular lymphoid hyperplasia of the lung. J Thorac Imaging 2005;20:239-241.

97 Song JY, Pittaluga S, Dunleavy K, Grant N, White T, Jiang L, Davies-Hill T, Raffeld M, Wilson WH, Jaffe ES: Lymphomatoid granulomatosis - a single institute experience: pathologic findings and clinical correlations. Am J Surg Pathol 2015;39:141-156.

98 Thomas de Montpréville V, Le Pavec J, Le Roy Ladurie F, Crutu A, Mussot S, Fabre D, Mercier O, Dorfmuller P, Ghigna MR, Fadel É: Lymphoproliferative disorders after lung transplantation: clinicopathological characterization of 16 cases with identification of very-late-onset forms. Respiration 2015;90: 451-459.

99 Beaty MW, Toro J, Sorbara L, Stern JB, Pittaluga S, Raffeld M, Wilson WH, Jaffe ES: Cutaneous lymphomatoid granulomatosis: correlation of clinical and biologic features. Am J Surg Pathol 2001;25:1111-1120.

100 Katzenstein AL, Carrington CB, Liebow AA: Lymphomatoid granulomatosis: a clinicopathologic study of 152 cases. Cancer 1979;43:360-373.

101 James WD, Odom RB, Katzenstein AL: Cutaneous manifestations of lymphomatoid granulomatosis. Report of 44 cases and a review of the literature. Arch Dermatol 1981; 117:196-202.

102 Katzenstein AL, Doxtader E, Narendra S: Lymphomatoid granulomatosis: insights gained over 4 decades. Am J Surg Pathol 2010;34:e35-e48.

103 Patsalides AD, Atac G, Hedge U, Janik J, Grant N, Jaffe ES, Dwyer A, Patronas NJ, Wilson WH: Lymphomatoid granulomatosis: abnormalities of the brain at MR imaging. Radiology 2005;237:265-273.
104 Gupta S, Gupta OP: Lymphomatoid granulomatosis of the oropharynx. Ear Nose Throat J 1980;59:152-154.

105 Hunter S, Samir A, Eisner B, Gervais D, Maher M, Hahn P, McGovern F, Mueller P: Diagnosis of renal lymphoma by percutaneous image guided biopsy: experience with 11 cases. J Urol 2006;176:1952-1956; discussion 1956.

106 Chung JH, Wu CC, Gilman MD, Palmer EL, Hasserjian RP, Shepard JA: Lymphomatoid granulomatosis: CT and FDG-PET findings. Korean J Radiol 2011;12:671-678.

107 Chavez JC, Sandoval-Sus J, Horna P, Dalia S, Bello C, Chevernick P, Sotomayor EM, Sokol L, Shah B: Lymphomatoid granulomatosis: a single institution experience and review of the literature. Clin Lymphoma Myeloma Leuk 2016;16(suppl):S170-S174.

108 Sabourin JC, Kanavaros P, Brière J, Lescs MC, Petrella T, Zafrani ES, Gaulard P: Epstein-Barr virus (EBV) genomes and EBVencoded latent membrane protein (LMP) in pulmonary lymphomas occurring in nonimmunocompromised patients. Am J Surg Pathol 1993;17:995-1002.

109 Swerdlow SH, Campo E, Harris NL, Jaffe ES, Pileri SA, Stein H, Thiele J, Vardiman JW: WHO Classification of Tumours of Haematopoietic and Lymphoid Tissues, ed 4. Geneva, WHO, 2008

110 Petrella TM, Walker IR, Jones GW, Leber B: Radiotherapy to control CNS lymphomatoid granulomatosis: a case report and review of the literature. Am J Hematol 1999; 62:239-241.

111 Jordan K, Grothey A, Grothe W, Kegel T, Wolf HH, Schmoll HJ: Successful treatment of mediastinal lymphomatoid granulomatosis with rituximab monotherapy. Eur J Haematol 2005;74:263-266.

112 Jaffre S, Jardin F, Dominique S, Duet E, Hubscher P, Genevois A, Corne F, Bota S, Nouvet G, Thiberville L: Fatal haemoptysis in a case of lymphomatoid granulomatosis treated with rituximab. Eur Respir J 2006; 27:644-646.

113 Wilson WH, Kingma DW, Raffeld M, Wittes RE, Jaffe ES: Association of lymphomatoid granulomatosis with Epstein-Barr viral infection of $\mathrm{B}$ lymphocytes and response to interferon-alpha 2b. Blood 1996; 87:4531-4537.

114 Johnston A, Coyle L, Nevell D: Prolonged remission of refractory lymphomatoid granulomatosis after autologous hemopoietic stem cell transplantation with posttransplantation maintenance interferon. Leuk Lymphoma 2006;47:323-328.

115 Chang Y, Cesarman E, Pessin MS, Lee F, Culpepper J, Knowles DM, Moore PS: Identification of herpesvirus-like DNA sequences in AIDS-associated Kaposi's sarcoma. Science 1994;266:1865-1869.
116 Soulier J, Grollet L, Oksenhendler E, Cacoub $\mathrm{P}$, Cazals-Hatem D, Babinet P, d'Agay MF, Clauvel JP, Raphael M, Degos L, et al: Kaposi's sarcoma-associated herpesvirus-like DNA sequences in multicentric Castleman's disease. Blood 1995;86:1276-1280.

117 Cesarman E, Chang Y, Moore PS, Said JW, Knowles DM: Kaposi's sarcoma-associated herpesvirus-like DNA sequences in AIDSrelated body-cavity-based lymphomas. N Engl J Med 1995;332:1186-1191.

118 Gantt S, Casper C: Human herpesvirus 8associated neoplasms: the roles of viral replication and antiviral treatment. Curr Opin Infect Dis 2011;24:295-301.

119 Verma S, Nuovo GJ, Porcu P, Baiocchi RA, Crowson AN, Magro CM: Epstein-Barr virus- and human herpesvirus 8-associated primary cutaneous plasmablastic lympho$\mathrm{ma}$ in the setting of renal transplantation. J Cutan Pathol 2005;32:35-39.

120 Hiatt KM, Nelson AM, Lichy JH, FanburgSmith JC: Classic Kaposi sarcoma in the United States over the last two decades: a clinicopathologic and molecular study of 438 non-HIV-related Kaposi sarcoma patients with comparison to HIV-related Kaposi sarcoma. Mod Pathol 2008;21:572582.

121 Marcelin AG, Motol J, Guihot A, Caumes E, Viard JP, Dussaix E, Cadranel J, Frances C, Carcelain G, Calvez V, Dupin N: Relationship between the quantity of Kaposi sarcoma-associated herpesvirus (KSHV) in peripheral blood and effusion fluid samples and KSHV-associated disease. J Infect Dis 2007;196:1163-1166

122 Uldrick TS, Wang V, O'Mahony D, Aleman K, Wyvill KM, Marshall V, Steinberg SM, Pittaluga S, Maric I, Whitby D, Tosato G, Little RF, Yarchoan R: An interleukin-6related systemic inflammatory syndrome in patients co-infected with Kaposi sarcomaassociated herpesvirus and HIV but without multicentric Castleman disease. Clin Infect Dis 2010;51:350-358.

123 Yuzuriha A, Saitoh T, Koiso H, Mitsui T, Uchiumi H, Yokohama A, Handa H, Kojima M, Tsukamoto N, Karaswa M, Murakami H, Nojima Y: Successful treatment of autoimmune hemolytic anemia associated with multicentric Castleman disease by anti-interleukin-6 receptor antibody (tocilizumab) therapy. Acta Haematol 2011;126: 147-150.

124 Suthaus J, Stuhlmann-Laeisz C, Tompkins VS, Rosean TR, Klapper W, Tosato G, Janz S, Scheller J, Rose-John S: HHV-8-encoded viral IL- 6 collaborates with mouse IL- 6 in the development of multicentric Castleman disease in mice. Blood 2012;119:5173-5181.

125 Schulz TF: The pleiotropic effects of Kaposi's sarcoma herpesvirus. J Pathol 2006;208: 187-198. 
126 Gao SJ, Kingsley L, Hoover DR, Spira TJ, Rinaldo CR, Saah A, Phair J, Detels R, Parry P, Chang Y, Moore PS: Seroconversion to antibodies against Kaposi's sarcoma-associated herpesvirus-related latent nuclear antigens before the development of Kaposi's sarcoma. N Engl J Med 1996;335:233-241.

127 Plancoulaine S, Abel L, van Beveren M, Trégouët DA, Joubert $M$, Tortevoye $P$, de Thé $\mathrm{G}$, Gessain A: Human herpesvirus 8 transmission from mother to child and between siblings in an endemic population. Lancet 2000;356:1062-1065.

128 Pauk J, Huang ML, Brodie SJ, Wald A, Koelle DM, Schacker T, Celum C, Selke S, Corey L: Mucosal shedding of human herpesvirus 8 in men. N Engl J Med 2000;343: 1369-1377.

129 Oksenhendler E, Cazals-Hatem D, Schulz TF, Barateau V, Grollet L, Sheldon J, Clauvel JP, Sigaux F, Agbalika F: Transient angiolymphoid hyperplasia and Kaposi's sarcoma after primary infection with human herpesvirus 8 in a patient with human immunodeficiency virus infection. N Engl J Med 1998;338:1585-1590.

130 Fajgenbaum DC, Uldrick TS, Bagg A, Frank D, Wu D, Srkalovic G, Simpson D, Liu AY, Menke D, Chandrakasan S, Lechowicz MJ, Wong RS, Pierson S, Paessler M, Rossi JF, Ide M, Ruth J, Croglio M, Suarez A, Krymskaya V, Chadburn A, Colleoni G, Nasta S, Jayanthan R, Nabel CS, Casper C, Dispenzieri A, Fosså A, Kelleher D, Kurzrock R, Voorhees P, Dogan A, Yoshizaki K, van Rhee F, Oksenhendler E, Jaffe ES, Elenitoba-Johnson KS, Lim MS: International, evidence-based consensus diagnostic criteria for HHV-8-negative/idiopathic multicentric Castleman disease. Blood 2017;129:1646-1657.

131 Oksenhendler E: Maladie(s) de Castleman; in Guillevin L, Meyer O, Sibilia J (eds): Traité des Maladies et syndromes systémiques, ed 5. Paris, Médecine-Sciences Flammarion, 2008, pp 917-927.

132 Oksenhendler E, Duarte M, Soulier J, Cacoub P, Welker Y, Cadranel J, CazalsHatem D, Autran B, Clauvel JP, Raphael M: Multicentric Castleman's disease in HIV infection: a clinical and pathological study of 20 patients. AIDS 1996;10:61-67.

133 Yeni P: Prise en charge médicale des personnes infectées par le VIH. Paris, Direction de l'information légale et administrative, 2010.

134 Mylona EE, Baraboutis IG, Lekakis LJ, Georgiou O, Papastamopoulos V, Skoutelis A: Multicentric Castleman's disease in HIV infection: a systematic review of the literature. AIDS Rev 2008;10:25-35.

135 Guihot A, Couderc LJ, Agbalika F, Galicier L, Bossi P, Rivaud E, Scherrer A, Zucman D, Katlama C, Oksenhendler E: Pulmonary manifestations of multicentric Castleman's disease in HIV infection: a clinical, biological and radiological study. Eur Respir J 2005; 26:118-125.
136 Guihot A, Couderc LJ, Rivaud E, Galicier L, Bossi P, Oksenhendler E, Scherrer A: Thoracic radiographic and $\mathrm{CT}$ findings of multicentric Castleman disease in HIV-infected patients. J Thorac Imaging 2007;22:207211.

137 Oksenhendler E, Carcelain G, Aoki Y, Boulanger E, Maillard A, Clauvel JP, Agbalika F: High levels of human herpesvirus 8 viral load, human interleukin-6, interleukin-10, and $\mathrm{C}$ reactive protein correlate with exacerbation of multicentric Castleman disease in HIV-infected patients. Blood 2000;96: 2069-2073.

138 El Karoui K, Vuiblet V, Dion D, Izzedine H, Guitard J, Frimat L, Delahousse M, Remy P, Boffa JJ, Pillebout E, Galicier L, Noel LH, Daugas E: Renal involvement in Castleman disease. Nephrol Dial Transplant 2011;26: 599-609.

139 London J, Boutboul D, Agbalika F, Coppo P, Veyradier A, Gérard L, Oksenhendler E, Azoulay E, Galicier L: Autoimmune thrombotic thrombocytopenic purpura associated with HHV8-related multicentric Castleman disease. Br J Haematol 2016, Epub ahead of print.

140 Simonelli C, Tedeschi R, Gloghini A, Talamini R, Bortolin MT, Berretta M, Spina M, Morassut S, Vaccher E, De Paoli P, Carbone A, Tirelli U: Plasma HHV-8 viral load in HHV-8-related lymphoproliferative disorders associated with HIV infection. J Med Virol 2009;81:888-896.

141 Stebbing J, Adams C, Sanitt A, Mletzko S, Nelson M, Gazzard B, Newsom-Davis T, Bower M: Plasma HHV8 DNA predicts relapse in individuals with HIV-associated multicentric Castleman disease. Blood 2011;118:271-275.

142 Levi JE, Nascimento MC, Sumita LM, de Souza VA, Freire WS, Mayaud P, Pannuti CS: Non-detection of human herpesvirus 8 (HHV-8) DNA in HHV-8-seropositive blood donors from three Brazilian regions. PLoS One 2011;6:e23546.

143 Oksenhendler E: HIV-associated multicentric Castleman disease. Curr Opin HIV AIDS 2009;4:16-21.

144 Dupin N, Diss TL, Kellam P, Tulliez M, Du MQ, Sicard D, Weiss RA, Isaacson PG, Boshoff C: HHV-8 is associated with a plasmablastic variant of Castleman disease that is linked to HHV-8-positive plasmablastic lymphoma. Blood 2000;95:1406-1412.

145 Du MQ, Bacon CM, Isaacson PG: Kaposi sarcoma-associated herpesvirus/human herpesvirus 8 and lymphoproliferative disorders. J Clin Pathol 2007;60:1350-1357.

146 Naresh KN, Rice AJ, Bower M: Lymph nodes involved by multicentric Castleman disease among HIV-positive individuals are often involved by Kaposi sarcoma. Am J Surg Pathol 2008;32:1006-1012.

147 Du MQ, Liu H, Diss TC, Ye H, Hamoudi RA, Dupin N, Meignin V, Oksenhendler E, Boshoff C, Isaacson PG: Kaposi sarcoma- associated herpesvirus infects monotypic (IgM $\lambda$ ) but polyclonal naive B cells in Castleman disease and associated lymphoproliferative disorders. Blood 2001;97:21302136.

148 Masaki Y, Kawabata H, Takai K, Kojima M, Tsukamoto N, Ishigaki Y, Kurose N, Ide M, Murakami J, Nara K, Yamamoto H, Ozawa Y, Takahashi H, Miura K, Miyauchi T, Yoshida S, Momoi A, Awano N, Ikushima S, Ohta Y, Furuta N, Fujimoto S, Kawanami H, Sakai T, Kawanami T, Fujita Y, Fukushima T, Nakamura S, Kinoshita T, Aoki S: Proposed diagnostic criteria, disease severity classification and treatment strategy for TAFRO syndrome, 2015 version. Int J Hematol 2016;103:686-692.

149 Hoffmann C, Schmid H, Müller M, Teutsch C, van Lunzen J, Esser S, Wolf T, Wyen C, Sabranski M, Horst HA, Reuter S, Vogel M, Jäger H, Bogner J, Arasteh K: Improved outcome with rituximab in patients with HIVassociated multicentric Castleman disease. Blood 2011;118:3499-3503.

150 Oksenhendler E, Boulanger E, Galicier L, Du MQ, Dupin N, Diss TC, Hamoudi R, Daniel MT, Agbalika F, Boshoff C, Clauvel JP, Isaacson PG, Meignin V: High incidence of Kaposi sarcoma-associated herpesvirusrelated non-Hodgkin lymphoma in patients with HIV infection and multicentric Castleman disease. Blood 2002;99:2331-2336.

151 Gérard L, Michot JM, Burcheri S, Fieschi C, Longuet P, Delcey V, Meignin V, Agbalika F, Chevret S, Oksenhendler E, Galicier L: Rituximab decreases the risk of lymphoma in patients with HIV-associated multicentric Castleman disease. Blood 2012;119: 2228-2233.

152 Bower M: How I treat HIV-associated multicentric Castleman disease. Blood 2010; 116:4415-4421.

153 Bérezné A, Agbalika F, Oksenhendler E: Failure of cidofovir in HIV-associated multicentric Castleman disease. Blood 2004; 103:4368-4369; author reply 4369.

154 Uldrick TS, Polizzotto MN, Aleman K, O’Mahony D, Wyvill KM, Wang V, Marshall V, Pittaluga S, Steinberg SM, Tosato G, Whitby D, Little RF, Yarchoan R: High-dose zidovudine plus valganciclovir for Kaposi sarcoma herpesvirus-associated multicentric Castleman disease: a pilot study of virus-activated cytotoxic therapy. Blood 2011; 117:6977-6986.

155 Buyse S, Teixeira L, Galicier L, Mariotte E, Lemiale V, Séguin A, Bertheau P, Canet E, de Labarthe A, Darmon M, Rybojad M, Schlemmer B, Azoulay E: Critical care management of patients with hemophagocytic lymphohistiocytosis. Intensive Care Med 2010;36:1695-1702.

156 Boshoff C, Begent RH, Oliver RT, Rustin GJ, Newlands ES, Andrews R, Skelton M, Holden L, Ong J: Secondary tumours following etoposide containing therapy for germ cell cancer. Ann Oncol 1995;6:35-40. 
157 Scott D, Cabral L, Harrington WJ Jr: Treatment of HIV-associated multicentric Castleman's disease with oral etoposide. Am J Hematol 2001;66:148-150.

158 Gérard L, Bérezné A, Galicier L, Meignin V, Obadia M, De Castro N, Jacomet C, Verdon $\mathrm{R}$, Madelaine-Chambrin I, Boulanger E, Chevret S, Agbalika F, Oksenhendler E: Prospective study of rituximab in chemotherapy-dependent human immunodeficiency virus associated multicentric Castleman's disease: ANRS 117 CastlemaB Trial. J Clin Oncol 2007;25:3350-3356.

159 Bower M, Powles T, Williams S, Davis TN, Atkins $\mathrm{M}$, Montoto S, Orkin C, Webb A, Fisher M, Nelson M, Gazzard B, Stebbing J, Kelleher P: Brief communication: rituximab in $\mathrm{HIV}$-associated multicentric Castleman disease. Ann Intern Med 2007;147:836-839.

160 Buchler T, Dubash S, Lee V, Chilton D, Cartledge J, Isaacson P, Tedder RS, Lee SM: Rituximab failure in fulminant multicentric HIV/human herpesvirus 8-associated Castleman's disease with multiorgan failure: report of two cases. AIDS 2008;22:1685-1687.

161 Marcelin AG, Aaron L, Mateus C, Gyan E, Gorin I, Viard JP, Calvez V, Dupin N: Rituximab therapy for HIV-associated Castleman disease. Blood 2003;102:2786-2788.

162 Schmidt SM, Raible A, Kortüm F, Mayer F, Riessen R, Adam P, Gregor M, Bissinger AL: Successful treatment of multicentric Castleman's disease with combined immunochemotherapy in an AIDS patient with multiorgan failure. Leukemia 2008;22:17821785.

163 Bestawros A, Michel R, Séguin C, Routy JP: Multicentric Castleman's disease treated with combination chemotherapy and rituximab in four HIV-positive men: a case series. Am J Hematol 2008;83:508-511.

164 Boulanger E, Brière J, Gaulard P, Droz D, Oksenhendler E: HHV8-related non-Hodgkin's lymphoma of the spermatic cord in a patient with $\mathrm{HIV}$-associated multicentric Castleman disease. Am J Hematol 2003;72: 70-71.

165 Guillet S, Gérard L, Meignin V, Agbalika F, Cuccini W, Denis B, Katlama C, Galicier L, Oksenhendler E: Classic and extracavitary primary effusion lymphoma in $51 \mathrm{HIV}$-infected patients from a single institution. Am J Hematol 2016;91:233-237.

166 Carbone A, Gaidano G: HHV-8-positive body-cavity-based lymphoma: a novel lymphoma entity. Br J Haematol 1997;97:515522 .
167 Olszewski AJ, Fallah J, Castillo JJ: Human immunodeficiency virus-associated lymphomas in the antiretroviral therapy era: Analysis of the National Cancer Data Base. Cancer 2016;122:2689-2697.

168 Boulanger E, Agbalika F, Maarek O, Daniel MT, Grollet L, Molina JM, Sigaux F, Oksenhendler E: A clinical, molecular and cytogenetic study of 12 cases of human herpesvirus 8 associated primary effusion lymphoma in HIV-infected patients. Hematol J 2001;2: 172-179.

169 Boulanger E, Gérard L, Gabarre J, Molina JM, Rapp C, Abino JF, Cadranel J, Chevret $\mathrm{S}$, Oksenhendler E: Prognostic factors and outcome of human herpesvirus 8 -associated primary effusion lymphoma in patients with AIDS. J Clin Oncol 2005;23:43724380.

170 Morassut S, Vaccher E, Balestreri L, Gloghini A, Gaidano G, Volpe R, Tirelli U, Carbone A: HIV-associated human herpesvirus 8-positive primary lymphomatous effusions: radiologic findings in six patients. Radiology 1997;205:459-463.

171 Carbone A, Gloghini A, Larocca LM, Capello D, Pierconti F, Canzonieri V, Tirelli U, Dalla-Favera R, Gaidano G: Expression profile of MUM1/IRF4, BCL-6, and CD138/ syndecan-1 defines novel histogenetic subsets of human immunodeficiency virus-related lymphomas. Blood 2001;97:744-751.

172 Gaidano G, Carbone A: Primary effusion lymphoma: a liquid phase lymphoma of fluid-filled body cavities. Adv Cancer Res 2001;80:115-146.

173 Fais F, Gaidano G, Capello D, Gloghini A, Ghiotto F, Roncella S, Carbone A, Chiorazzi $\mathrm{N}$, Ferrarini M: Immunoglobulin $\mathrm{V}$ region gene use and structure suggest antigen selection in AIDS-related primary effusion lymphomas. Leukemia 1999;13:1093-1099.

174 Luan SL, Boulanger E, Ye H, Chanudet E, Johnson N, Hamoudi RA, Bacon CM, Liu H, Huang Y, Said J, Chu P, Clemen CS, Cesarman E, Chadburn A, Isaacson PG, Du MQ: Primary effusion lymphoma: genomic profiling revealed amplification of SELPLG and CORO1C encoding for proteins important for cell migration. J Pathol 2010;222: 166-179.
175 Carbone A, Gloghini A, Vaccher E, Zagonel V, Pastore C, Dalla Palma P, Branz F, Saglio G, Volpe R, Tirelli U, Gaidano G: Kaposi's sarcoma-associated herpesvirus DNA sequences in AIDS-related and AIDS-unrelated lymphomatous effusions. Br J Haematol 1996;94:533-543.

176 Galicier L, Fieschi C, Borie R, Meignin V, Daniel MT, Gérard L, Oksenhendler E: Intensive chemotherapy regimen (LMB86) for St Jude stage IV AIDS-related Burkitt lymphoma/leukemia: a prospective study. Blood 2007;110:2846-2854.

177 Oksenhendler E, Clauvel JP, Jouveshomme S, Davi F, Mansour G: Complete remission of a primary effusion lymphoma with antiretroviral therapy. Am J Hematol 1998;57: 266.

178 Castillo JJ, Shum H, Lahijani M, Winer ES, Butera JN: Prognosis in primary effusion lymphoma is associated with the number of body cavities involved. Leuk Lymphoma 2012;53:2378-2382.

179 Gupta A, Sen S, Marley E, Chen W, Naina HV: Management and outcomes of HIVassociated primary effusion lymphoma: a single center experience. Clin Lymphoma Myeloma Leuk 2016;16(suppl):S175-S180.

180 Boulanger E, Daniel MT, Agbalika F, Oksenhendler E: Combined chemotherapy including high-dose methotrexate in KSHV/ HHV8-associated primary effusion lymphoma. Am J Hematol 2003;73:143-148.

181 Boulanger E, Meignin V, Oksenhendler E: Bortezomib (PS-341) in patients with human herpesvirus 8 -associated primary effusion lymphoma. Br J Haematol 2008; 141: 559-561.

182 Gasperini P, Tosato G: Targeting the mammalian target of rapamycin to inhibit VEGF and cytokines for the treatment of primary effusion lymphoma. Leukemia 2009;23: 1867-1874.

183 Luppi M, Trovato R, Barozzi P, Vallisa D, Rossi G, Re A, Ravazzini L, Potenza L, Riva G, Morselli M, Longo G, Cavanna L, Roncaglia R, Torelli G: Treatment of herpesvirus associated primary effusion lymphoma with intracavity cidofovir. Leukemia 2005; 19: 473-476.

184 Birsen R, Boutboul D, Crestani B, SeguinGivelet A, Fieschi C, Bertinchamp R, Giol M, Malphettes M, Oksenhendler E, Galicier $\mathrm{L}$ : Talc pleurodesis allows long-term remission in HIV-unrelated human herpesvirus 8 -associated primary effusion lymphoma. Leuk Lymphoma 2017;58:1993-1998. 